\title{
Climate Change Vulnerability and Disaster Risk Assessment Using Remote Sensing Technology and Adaptation Strategies for Resiliency and Disaster Risk Management in Selected Coastal Municipalities of Zambales, Philippines
}

\author{
Annie Melinda Paz-Alberto, Eliza Camaso, Roann P. Alberto, Daryl A. Juganas, \\ Kathrina M. Mapanao, Carl Dionelle B. Ponce, Christopher Genaro \\ Institute for Climate Change and Environmental Management, Central Luzon State University, Science City of Muñoz, \\ Philippines \\ Email: anniealberto@clsu.edu.ph, eecamaso@clsu.edu.ph, annplaoalberto@clsu.edu.ph, mapanaokathrina@gmail.com, \\ daryljuganas@clsu.edu.ph, carldionelle@clsu.edu.ph
}

How to cite this paper: Paz-Alberto, A M., Camaso, E., Alberto, R. P., Juganas, D. A., Mapanao, K. M., Ponce, C. D. B., \& Genaro, C. (2021). Climate Change Vulnerability and Disaster Risk Assessment Using Remote Sensing Technology and Adaptation Strategies for Resiliency and Disaster Risk Management in Selected Coastal Municipalities of Zambales, Philippines. American Journal of Climate Change, 10, 85-133.

https://doi.org/10.4236/ajcc.2021.101005

Received: November 23, 2020

Accepted: March 27, 2021

Published: March 30, 2021

Copyright $\odot 2021$ by author(s) and Scientific Research Publishing Inc. This work is licensed under the Creative Commons Attribution International License (CC BY 4.0)

http://creativecommons.org/licenses/by/4.0/ (c) (i) Open Access

\begin{abstract}
The Philippines is one of the most hazard prone and vulnerable countries in the world to climate change effects due to its geographical location. Climate change is already happening and affecting many places causing huge problems to coastal ecosystems. Vulnerability and disaster assessment and mapping in coastal areas are essential tasks and undertakings for coastal disaster risk management. The objectives of this study were to assess the climate change vulnerability and disaster risks in the four municipalities (Sta. Cruz, Candelaria, Masinloc and Palauig) of Zambales and to determine the climate change community-based adaptation (CBA) and ecosystem-based adaptation (EBA) strategies. Remote sensing, GIS, secondary data gathering and key informant interview were used to assess vulnerability and disaster risks and mapping in the four municipalities. Survey questionnaire, focus group discussion and key informant interview were utilized in gathering data for the determination of climate change adaptation strategies. Using remote sensing technology, it was revealed that coastline changes have occurred in the shorelines of the four coastal municipalities after a decade. Sea level rise happened in Sta. Cruz and Masinloc, Zambales while there was build-up of soil in the coastline of Candelaria and Palauig, Zambales. Twelve hazard maps, 12 vulnerability maps and 12 disaster risk maps were generated for the three major disasters (flood, landslide, storm surge) in the four coastal municipalities. Based on the flood vulnerability and disaster risk assessment, the municipali-
\end{abstract}


ty of Palauig was found to be the most prone to flooding while the municipality of Candelaria was found to be the most vulnerable to landslide compared to other municipalities. All coastal barangays in the four municipalities were susceptible to storm surge. The four coastal municipalities were conducting community-based adaptation (CBA) and ecosystem-based adaptation (EBA) approaches in order to protect their coastal resources from the damaging impacts of climate change and improve the resilience of their local communities.

\section{Keywords}

Climate Change, Vulnerability Assessment, Disaster Risk, Remote Sensing, Community-Based Adaptation, Ecosystem-Based Adaptation

\section{Introduction}

Climate change is one of the twenty-first century's most pressing problems. Climate change is happening and affecting many places causing huge problems to agriculture, coastal and forest ecosystems. Coastal resource degradation becomes more complex due to climate change impacts and occurrence of natural hazards. There are many factors causing the Earth's climate to change. According to the United Nation Framework Convention on Climate Change (UNFCC) climate change is attributed directly and indirectly to human activities that alter the composition of the global atmosphere. The Philippines is one of the most hazard prone or vulnerable countries in the world due to its geographical location and is also one of the most susceptible to climate change effects with an average of 19 - 20 typhoons per year. The Philippines takes a serious view of the potential effects and possible responses to these kinds of hazards and disasters.

Vulnerability is defined as the characteristics of a structural, person or group and their situation that influences their capacity to anticipate, cope with, resist and recover from the impact of a hazardous event. Vulnerability is a function of exposure, sensitivity and lack of hazard adaptive capacity to hazardous events. It directly affects disaster preparation, response and recovery. Hazardous events can result in a detrimental impact on individual and/or their asset (Du et al., 2015). On the other hand, disaster is defined by the United Nations International Strategy for Disaster Risk Reduction (UNISDR, 2004) as "a serious disruption of the functioning of a community or a society causing widespread human, material, economic or environmental losses which exceed the ability of the affected community or society to cope using its own resources".

The country has suffered from an inexhaustible number of climate change impacts from extreme weather events such as torrential rains, strong typhoons which lead to deadly hazards and disasters such as floods, landslides, storm surge, etc. Hence, the vast populations settled in both urban and rural coastal 
areas are particularly vulnerable. Global climate change is expected to increase the frequency and intensity of climate related hazards (IPCC, 2007).

Remote sensing is the science of acquiring information about the Earth using satellite images. This technology is very useful for disaster risk management. Utilization of remote sensing and application of Geographic Information System (GIS) information are new technologies to assess vulnerability and disaster risks in any area. Remote sensing can be used to assist risk reduction initiatives through identification of hazard zones associated with flood plains, coastal inundation and erosion. Remote sensing applications in monitoring coastlines offer fast, cheap and reliable data acquisition. Geophysical changes that occurred in the past and are happening at present times project how the area was utilized or affected by natural occurrences and climate change. On the other hand, remote sensing and GIS are valuable for hazard, vulnerability and disaster risk mapping and these maps are handy for the use of local communities in the course of emergency situations. These also provide decision support system in disaster risk management.

In response to the need to tackle the detrimental effects of climate change, the Philippines has conducted several projects and implemented some measures in order to improve the resilience of the country. In reality, the effects of climate change are becoming more harmful due to the bad state of the environment and the socioeconomic circumstances of the people. Adaptation strategies for climate change play a crucial role in every society, particularly in coastal areas, where the impacts of climate change (sea-level rise, temperature rise, heavy rainfall, coastal erosion, sedimentation, powerful typhoons, storm surge), and other climate change effects were high. The climate change adaptation strategies are designed to educate and help communities in identifying prospective options. Climate change adaptation refers to "adjustment in natural or human systems in response to actual or expected climatic stimuli or their effects, which moderates harm or exploits beneficial opportunities" (IPCC, 2001). They are illustrative and submitted to assist communities in identifying feasible methods to tackle expected present and future threats arising from the changing climate. The NFSCC 2010-2022 proposes an integrated ecosystem-based management strategy to address the country's numerous climate change vulnerabilities. It goes beyond being simply an environmental issue with significant social and economic effects that threaten the survival of human beings.

In the Philippines, climate change adaptation makes a significant contribution to gross domestic product and provides coastal communities with livelihood possibilities. Climate change adaptation benefits entities, communities, and natural systems to deal with those costs of climate change that cannot be escaped. It includes taking practical actions to manage risks from impacts of changing climate, protect communities and fortify the resilience of the economy.

Coastal resource degradation becomes more complex due to climate change phenomenon and occurrence of natural hazards. United Nation Framework Convention on Climate Change (UNFCCC) emphasizes that change of climate is 
attributed directly and indirectly to human activities that alter the composition of the global atmosphere. The starting point for reducing disaster risk lies in the knowledge of the hazard and vulnerability and of the ways in which these are changing in the short and long term, followed by action taken on the basis of that knowledge (UNISDR, 2005).

Zambales is a province situated in Central Luzon, bounded on the north by Pangasinan, Tarlac and Pampanga on the east; Bataan on the south; and West Philippine Sea on the west. It has an aggregate area of $3714.40 \mathrm{~km}^{2}$ with two pronounced seasons: dry (October to June) and wet (July to September). The province of Zambales has a total coastal area of 56,792.25 ha and $232.6 \mathrm{~km}$ coastline. Tha coastal municipalities of Palauig, Masinloc, Candelaria and Sta Cruz had also various aquatic and terrestrial ecosyems such as rivers, lakes, wetlands, seagrasses, coral reefs, mangroves and forests, respectively (Philippine Mangroves: Biodiversity, Conservation and Management, 2014).

These ecosystems were also declared protected areas locally and by the national government such as the Masinloc-Oyon Bay Seascape and Landscape, Uacon Lake, Panglit Protected Area (San Salvador Island), Hermana Mayor and Hermana Menor and Mt. Tapulao among others. Coastal ecosystems in the province of Zambales have been facing a lot of pressures from the anthropogenic activities that have exacerbated by changing climate and occurrence of natural hazards. Human activities can bring detrimental effects in the coastal ecosystems, land and water.

\section{Materials and Methods}

\subsection{The Study Area}

The study covered the coastal barangays of four municipalities in the province of Zambales which comprised of thirteen (13) barangays from Palauig, ten (10) barangays from Masinloc, eight (8) barangays from Candelaria and eleven (11) barangays from Sta. Cruz (Figure 1).

\subsection{Physical and Chemical Characteristics of the Coastal Ecosystems}

\subsubsection{Water Sampling and Analysis}

Four stations in each of the coastal ecosystem were established and identified in the four selected municipalities such as Sta. Cruz, Candelaria, Masinloc and Palauig. The physical, and chemical characteristics of the coastal water within the sampling sites were determined.

Careful cleansing and rinsing of sample containers (catsup bottles) were done with powdered detergent dissolved in water. These bottles were sterilized before they were used as containers for the samples.

\subsubsection{Physical Characteristics}

In situ analysis of physical parameters was done. Temperature was gathered using a portable laboratory mercury thermometer or other available instrument. 


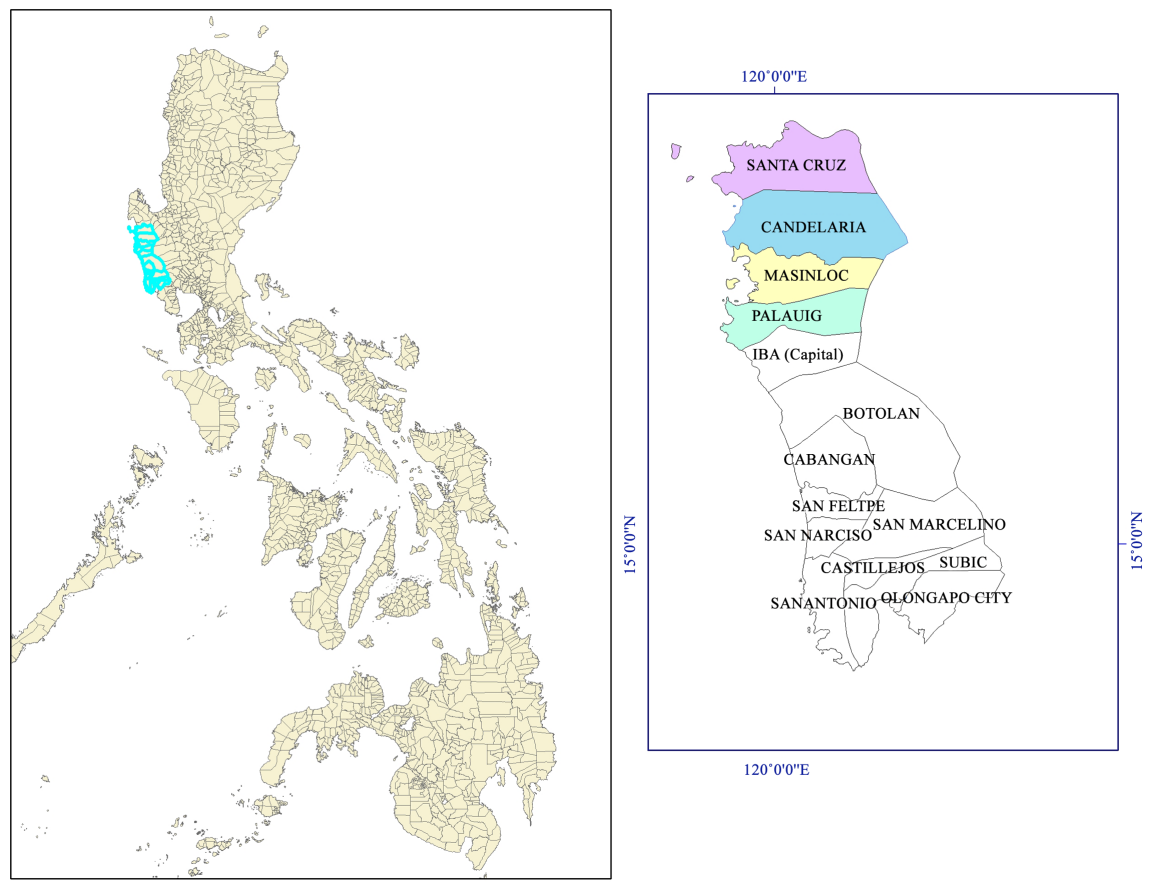

Figure 1. Study areas: Sta. Cruz, Candelaria, Masinloc and Palauig, Zambales.

This was submerged immediately below the water surface for 5 minutes. Reading was done while the instrument was in the water to avoid inaccuracy of the temperature reading. This was done three times per station at varying depths within the coastal area.

\subsubsection{Chemical Characteristics}

The $\mathrm{pH}$ and salinity were analyzed in-situ. The $\mathrm{pH}$ of the water samples from every sampling station was taken by using a digital pen-type $\mathrm{pH}$ meter or any available instrument to get the $\mathrm{pH}$ of the water. A water sample was taken and placed in a beaker then the $\mathrm{pH}$ meter was dipped until the probe mark. When the readings appeared on the $\mathrm{pH}$ meter screen, and it was stabilized, this reading was recorded as the $\mathrm{pH}$ measurement. In measuring the salinity, a drop of water sample was taken in the sampling site and placed into the glass mount of the refracto-salinometer or any available instrument.

The water samples were collected from each sampling station for the analysis of ammonia, nitrite, phosphate and total suspended solids (TSS). Water samples for laboratory analysis were collected at 4 to 5 feet depth from the sampling stations during day time. Sterilized bottles were dipped 6 inches below the surface of the water. The bottles were held by the hand near the base and plunged, neck downward from the middle of the surface water then turned the bottle until the neck pointed slightly upward against the water flow. These bottles were labeled according to the station where water samples are collected. These will be put into a cooler with ice to maintain the temperature of $40^{\circ} \mathrm{C}$ while being transported to the laboratory. The water samples were examined within 24-hour period after they were taken from the site. Laboratory analysis was done in the CRL Labora- 
tory, Clarkfield, Pampanga.

\subsubsection{Treatment and Analysis of Data}

Gathered data on water quality were tabulated and analyzed using their mean/average. These were compared to the standards set by the Department of Environment and Natural Resources (DENR) and Association of Southeast Asian Nation (ASEAN).

\subsubsection{Sediment Sampling and Analysis}

The sediment samples were gathered in the sampling stations of the coastal ecosystems in the four selected municipalities using composite sampling. The dipper method from CRL protocol was used to collect the sediment sample. A stainless steel dipper was used to collect the sample by pushing it firmly downward into the sediment and then quickly lifting it upward to reduce the amount of fine grained sediment lost to the water current. One scoop of sediment was dug in every quadrat during the survey totaling to ten scoops per station. Then the sediment samples from each composite location were transferred in a stainless steel bowl. After the samples were gathered, the samples were homogenized using stainless spoon before filling in a clean glass container and were labeled properly.

After the collection, the glass containers with sediment were stored in an ice chest filled with bagged ice. The preparation of the sediment samples was done in the CRL Laboratory, Clarkfield, Pampanga to test and analyze the presence of lead, chromium, cadmium and copper and toxic chemicals/heavy metals as well as nutrient elements that may be present in the sediments.

\subsubsection{Determination of Sediment Load}

Sediment trapping in the selected coastal ecosystems was done using an improvised sediment trap equipment. A bottle served as collecting jar. The funnel opening had baffles at the top to keep out very large objects that might clog the opening funnel. The traps were placed in certain depth to a fixed cable attached to an anchor or buoy. They were deployed and collection of sediments was done after two weeks. Collected samples were dried and weighed to determine the amount of sediments being carried/transported to the various coastal ecosystems in the selected study sites.

\subsubsection{Shoreline Tracing For Determination of Coastline Changes}

Shoreline tracing involved the tracking of the current position of the shoreline with the use of a handheld Geographic Position System (GPS) instrument. The GPS points were recorded as waypoints every 20 steps. Recording was done either manually or automatically.

The shoreline drawn in the 1:50,000 NAMRIA topographic map was referenced to mean sea level (MSL), which was located between the high and low-tide waterlines. To be consistent with NAMRIA maps, shoreline tracing is usually done at the waterline, or the boundary between wet and dry for sand. For 
safety reasons in high energy, steep beaches (slope of 1:10), the trace can be done at the mid-swash, or approximately, midway of low and high-tides limits.

The water line was traced as the shoreline. Along high energy and steep beaches, mid-tide waterline, which approximates the mid-swash, should be traced. On reef flats and muds/sandflats, or along beaches with gentle gradients shoreline tracing was done at the beach toe, which was marked by a break in a slope, and change a sediment size. The coastline in the year 2009 was the basis of the measurement. Coastline images for the years 2009-2019 were gathered from the Google Earth images and were measured every 100 meters (Paz-Alberto, et al., 2016). Using the remote sensing technology historical maps were generated.

\subsection{Climate Change Vulnerability and Disaster Risk Assessment}

\subsubsection{Reconnaissance Survey}

The general approach in implementing preliminary disaster risk assessment through community based participatory approach is building a more in depth understanding of the potential socio-economic impacts of the climate hazards as well as verify the existence of important non-geophysical issues related to those who are directly affected.

\subsubsection{Hazard Assessment}

Shape files of administrative boundaries of the four municipalities (municipal and barangay) were obtained from their respective Municipal Planning and Development Offices (MPDOs). The administrative boundaries were subdivided into one-hectare grid to ensure that scoring of hazard susceptibility was very specific in that area.

\subsubsection{Household and Key Informant Surveys}

Household survey was conducted in the four (4) municipalities to determine the level of hazard awareness and adaptive strategies as indicators of adaptive capacity. Sample size was computed using the Slovin's formula (Equation (1)).

$$
n=\frac{N}{1+N e^{2}}
$$

where:

$$
\begin{aligned}
& n=\text { sample size for each municipality; } \\
& N=\text { total population of each of each municipality; } \\
& e=\text { margin of error }(10 \%)
\end{aligned}
$$

\subsubsection{Vulnerability Assessment}

This study adopted the methodology developed by Espaldon et al. (2016) and Paz-Alberto et al. (2018). A vulnerability assessment checklist was prepared and used to assess the vulnerability of the study sites. Vulnerability index score was computed using equation devised by Hoeurn (2013) (Equation (2)):

$$
V_{i}=\frac{E_{i}+S_{i}+A C_{i}}{3}
$$


where:

$V_{i}=$ vulnerability index score in grid $i$.

$E_{i}=$ exposure index score in grid $i$.

$S_{i}=$ sensitivity index score in grid $i$.

$A C_{i}=$ adaptive capacity index score in grid $i$.

The categories and scale range used for sensitivity, exposure and adaptive capacity was developed by Paz-Alberto et al., (2018) and was utilized by the study.

\subsubsection{Secondary Data Gathering}

Secondary data were gathered from the municipalities of Sta. Cruz, Candelaria, Masinloc and Palauig, Zambales to establish the profile of the four municipalities and were used for the vulnerability assessment.

These were municipal agricultural profile, population disaster risk reduction and mitigation plans, history of destructive events in the municipality such as flooding, landslide, storm surge and tsunami, Comprehensive Land Use Plan (CLUP), areas (barangays) that are affected by the natural hazards.

\subsubsection{Disaster Risk Assessment}

Disaster risk index score of each grid was computed using Equation (3):

$$
D R_{i}=H_{i} \times V_{i}
$$

where:

$D R_{i}=$ disaster risk index score in grid $i$.

$H_{i}=$ hazard susceptibility index score in grid $i$.

$V_{i}=$ vulnerability index score in grid $i$.

\subsection{Climate Change Adaptation Strategies}

\subsubsection{Data Collection}

The research used a mixture of information collection methods such as secondary data collection, primary data collection through household survey, key informant interviews, and focus group discussion. The researchers surveyed coastal residents living along the coastal areas of the four (4) municipalities to determine the incidences of climate change-related events and the climate change adaptation strategies that they are conducting to lessen and prevent impacts of climate change. The respondents from the thirty barangays were the households dwelling along the coastline of Palauig, Candelaria, Sta. Cruz, and Masinloc, Zambales. Survey interviews, focus group discussion (FGD), and key informant interview (KII) were used through random sampling to determine their understanding and perception about climate change science, climate change effects, and to assess their climate change adaptation strategies.

\subsubsection{Secondary Data Gathering}

The secondary collection of the socio-economic data were obtained from the local government units of the four municipalities (Sta. Cruz, Candelaria, Palauig, and Masinloc). Information sources include municipal and provincial develop- 
ment plans, socio-demographic data from the municipal, agricultural office, fisher folk registration and other relevant information from various institutional stakeholders in the four coastal municipalities.

Meanwhile, the researchers gathered data from the Municipal Disaster Risk Reduction Management Office (MDRRMO) on historical information about natural disasters such as greater typhoons, storm surge, coastal erosion, tsunami, and other phenomena that happened in Zambales.

\subsubsection{Focus Group Discussion}

During the focus group discussion the respondents were asked to identify the sectors vulnerable to climate change impacts in order to determine the presence of climate change adaptation strategies implemented in the area to identify the applicable and best approaches to cope up with climate change (e.g. Soft and Hard measures), their importance, implementation status, and those applicable adaptation strategies for climate change impacts such as problems in flooding, strong typhoons, torrential rains, etc. Likewise, coastal community-based adaptation strategies and environmental/ecosystem-based approaches to combat climate change impacts were also determined together with the action plans of each coastal barangay in every municipality in order for them to become resilient, ready, alert, and prepared in case of sea level rise, strong typhoons, flood, and storm surge that may occur in their coastal barangays.

After analyzing the information, the researchers identify the best pool of feasible alternatives and developed the most suitable climate change strategies particular to the needs of the coastal barangays in Zambales.

\subsubsection{Key Informant Interview}

The researchers interviewed the department or unit heads of Agriculture Office, Disaster Risk Reduction Management Office, and Coastal Resource Management/Environment and Natural Resources Office from the Municipalities of Sta, Cruz, Candelaria, Palauig, and Masinloc for the key informant interview. Moreover, the researchers interviewed the Provincial Agricultural Office (PAO), Provincial Disaster Risk Reduction Management (PDRRM), and the Philippine Red Cross of Zambales.

\section{Results and Discussion}

\subsection{Physical and Chemical Characteristics}

In situ analysis of physical parameters was done in the four (4) selected coastal ecosystems of Zambales such as water temperature, air temperature and $\mathrm{pH}$ level. Results showed that the average air temperature recorded in the coastal ecosystems of Masinloc and Palauig, Zambales were both $32^{\circ} \mathrm{C}$, this is followed by Sta. Cruz, Zambales and Candelaria, Zambales with $31^{\circ} \mathrm{C}$ and $30^{\circ} \mathrm{C}$, respectively. The coastal water had an average temperature of $28^{\circ} \mathrm{C}-29^{\circ} \mathrm{C}$ for all the coastal municipalities surveyed. This is due to the intense occurrence of South West Monsoon (Habagat) during the fieldwork activities. The air temperature ob- 
tained was above the average air temperature in Zambales region which is $26^{\circ} \mathrm{C}$ $28^{\circ} \mathrm{C}$ while the water temperature obtained was below the average sea surface temperature of $30^{\circ} \mathrm{C}-31^{\circ} \mathrm{C}$.

The $\mathrm{pH}$ level measurement was also analyzed in -situ and the results showed that the average $\mathrm{pH}$ level in water of the four coastal ecosystems ranged from $\mathrm{pH}$ 7.7 to $\mathrm{pH}$ 8.0. Furthermore, the $\mathrm{pH}$ level of coastal water was also within the safe level which is 7.5 to $8.5 \mathrm{pH}$ for sea water. The data on water quality were tabulated and analyzed using their mean/average.

In addition, Sta. Cruz, Zambales had the highest Total Suspended Solids (TSS), with a value of $31.7 \mathrm{mg} / \mathrm{L}$. This was followed by Masinloc with $22 \mathrm{mg} / \mathrm{L}$ TSS and the lowest TSS was obtained by Candelaria, Zambales, with $18 \mathrm{mg} / \mathrm{L}$. Results showed that TSS in the coastal water of the four municipalities was low. The acceptable and standard limit for TSS in coastal water is $150-200 \mathrm{mg} / \mathrm{L}$. The TSS and turbidity indicate water quality. TSS are particles that are larger than 2 microns found in the water column and most suspended solids are made up of inorganic materials such as sediment, silt, sand, planktons, algae, organic particles from decomposing materials and chemical precipitates. The more solids present in the water, the less clear the water will be (USEPA, 2002).

Furthermore, the amount of ammonia, nitrite, phosphate and salinity in water were also determined. Masinloc, Zambales had the highest amount of ammonia in surface water, with $0.05 \mathrm{mg} / \mathrm{l}$ ammonia. This was followed by Sta. Cruz, Zambales and Palauig, Zambales, with $0.05 \mathrm{mg} / \mathrm{L}$ and $0.04 \mathrm{mg} / \mathrm{L}$ ammonia in surface water, respectively. The lowest amount of ammonia in water was recorded in Candelaria, Zambales, with $0.03 \mathrm{mg} / \mathrm{L}$ ammonia. The amount of ammonia in the four coastal ecosystems is within the safe level. According to US Environmental Protection Agency (USEPA) the environmental limits for ammonia in surface water range from 0.25 to $32.5 \mathrm{mg} / \mathrm{l}$ (ppm). For the amount of nitrite and phosphate in surface water, the four coastal municipalities had obtained low values, with only $<0.004 \mathrm{mg} / \mathrm{L}$ nitrite and $<0.01 \mathrm{mg} / \mathrm{L}$ phosphate. All the coastal ecosystems surveyed are within the safe limit for both phosphate and nitrite in water. The acceptable limit for phosphate and nitrite in surface water is $0.01 \mathrm{mg} / \mathrm{L}$ and 45 - $100 \mathrm{mg} / \mathrm{L}$, respectively (USEPA, 2002). Moreover, the highest amount of saline in water was recorded in Palauig, Zambales, with an average salinity of $31,100 \mathrm{mg} / \mathrm{L}$ in the surface water. This was followed by Masinloc, Zambales and Sta. Cruz, Zambales, with salinity of $30,650 \mathrm{mg} / \mathrm{L}$ and $30,233 \mathrm{mg} / \mathrm{L}$, respectively. The lowest salinity was recorded in Candelaria, Zambales, with an average salinity of $22,900 \mathrm{mg} / \mathrm{L}$. The salt concentration or salinity of the sea surface in the coastal ecosystems surveyed fell below the standard limit of salinity which ranged from 32 38 parts per thousand (ppt)/32,000 - 38,000 mg/L. These results maybe due to the weather system and weather pattern that affect the region during the conduct of the study which is the Southwest Monsoon (Habagat) from May to November (Wet Season). As seawater evaporates the salt remains behind, only the freshwater is transferred from the ocean to the atmosphere which also indicates that the region of excess evaporation, such as the subtropics tends to become salty, while the 
areas of excess rainfall become fresher (Gordon, 2000).

\subsection{Determination of Sediment Load}

Sediment trapping in the four coastal ecosystems was done using an improvised sediment trap equipment. The sediment trap gadgets were deployed and the collection of sediments was done after two weeks. Collected samples were dried and weighed to determine the amount of sediments being transported to the various coastal ecosystems in the selected study sites. Table 1 presents the sediment load analysis in the coastal ecosystems of Palauig, Masinloc, Candelaria and Sta. Cruz, Zambales during the conduct of the study.

The highest average sediment load was obtained by Masinloc, Zambales with $10.03 \mathrm{~g}$ of sediment load in all the stations surveyed. This was followed by Candelaria and Palauig, Zambales with an average sediment load of $8.10 \mathrm{~g}$ and 7.16 g, respectively. The lowest sediment load was recorded in Sta. Cruz, Zambales with an average sediment load of $5.94 \mathrm{~g}$. Results showed that there was high rate of sedimentation occurred in the four coastal municipalities of Zambales. Most of the sediments in various coastal ecosystems are carried by the streams and rivers in the area and it may cause sedimentation which can affect the coastal ecosystems of Zambales.

\subsection{Coastline Changes in Selected Coastal Resources}

The current position of the shoreline in the four coastal municipalities of Zambales was determined using Global Positioning System (GPS). Using the application of Geographic Information System (GIS), preliminary plots had been used to track down all the waypoints recorded. Using the application of remote sensing technology historical maps were obtained and data from the Google Earth were used and scaled to lay out the tracks from the GIS.

Results revealed that there are approximately 600 meters of shoreline in Sta. Cruz, Zambales, $1100 \mathrm{~m}$ shoreline in Masinloc, Zambales, $1800 \mathrm{~m}$ shoreline in Palauig, Zambales and $2200 \mathrm{~m}$ of shoreline in Candelaria, Zambales that had been traced and the occurrence of mangrove, seagrass and coral reef ecosystems in the areas were also evident. Table 2 shows the coastal changes in the coastline of Sta. Cruz, Zambales.

Table 1. Sediment load analysis in the coastal ecosystems of Palauig, Masinloc, Candelaria and Sta. Cruz, Zambales.

\begin{tabular}{ccccc}
\hline \multirow{2}{*}{ Sediment Load } & \multicolumn{3}{c}{ Location } \\
\cline { 2 - 4 } & Sta. Cruz & Candelaria & Masinloc & Palauig \\
\hline Transect 1 & $5.24 \mathrm{~g}$ & $5.47 \mathrm{~g}$ & $9.81 \mathrm{~g}$ & $8.68 \mathrm{~g}$ \\
Transect 2 & $3.64 \mathrm{~g}$ & $8.68 \mathrm{~g}$ & $11.52 \mathrm{~g}$ & $6.80 \mathrm{~g}$ \\
Transect 3 & $8.93 \mathrm{~g}$ & $10.16 \mathrm{~g}$ & $8.77 \mathrm{~g} \mathrm{~g}$ & $5.99 \mathrm{~g}$ \\
Average & $5.94 \mathrm{~g}$ & $8.10 \mathrm{~g}$ & $10.03 \mathrm{~g}$ & $7.16 \mathrm{~g}$ \\
\hline
\end{tabular}


Table 2. Coastline changes in Sta Cruz, Zambales.

\begin{tabular}{cccccccc}
\hline \multirow{2}{*}{$\begin{array}{c}\text { 10-Year } \\
\text { Historical Data }\end{array}$} & \multicolumn{9}{c}{ Points (m) } & \multirow{2}{*}{ Average } \\
\cline { 2 - 7 } & 100 & 200 & 300 & 400 & 500 & 600 & \\
\hline 2009 & 0 & 0 & 0 & 0 & 0 & 0 & 0 \\
2014 & -3.34 & -7.28 & -3.02 & -2.37 & -2.42 & 4 & -2.40 \\
2019 & -13.55 & -13.48 & -8.67 & -10.11 & -8 & -3.57 & -9.56 \\
Field Data (2019) & -14.23 & -12.75 & -7.54 & -11.70 & -9 & -5.24 & -10.08 \\
\hline
\end{tabular}

Results showed that an average of 10.08 meters of sea level rise had occurred in the 600 meters shoreline that was traced in the coastal barangays of Sta. Cruz, Zambales based on the distance measured and analysis on the 10-year historical and actual data gathered from 2009 to 2019 shoreline tracing. Furthermore, Figure 2 shows the detailed graph of the changes in the coastline of Sta. Cruz, Zambales. Results indicated that the highest rate of sea level rise are located at points 1, 2 and 4 of the coastline while point 6 shows that there is a minimal occurrence of sea level rise. Root Mean Square Error (RMSE) was also computed in the coastline of Sta. Cruz, Zambales to determine the differences of the field data and the plotted data in Google Earth. The RMSE computed for the coastline of Sta Cruz is 1.13 meters and it shows minimal differences between the field data and Google Earth data. According to Paz-Alberto., et al., 2016, these findings revealed that Google Earth historical high resolution imageries provide positional accuracies which can be used for small scale data sets and can be used for investigation and preliminary studies with high accuracy and low cost. Moreover, the 15 years average historical tide levels recorded in Zambales show that there was an average of 0.61 masl increase in the tide level which could also affect and contribute to the sea level rise in the coastal area of Sta Cruz. (Figure 3).

One of the many factors affecting the coastal erosion in Sta. Cruz, Zambales is the sea level rise. According to the study conducted by Taguiam and Quiambao (2016), there are already changes in the shoreline of Sta. Cruz, Zambales, the water moved landward and caused the shortening of coastline. As residents for a long-period of time near the coasts, the local communities witnessed and experienced the effects and impacts of sea level rise and many of them considered relocation and they were doing adaptation measures which were applicable in their areas such as repairing and elevating their houses.

Table 3 shows the rate of the sedimentation or build up of soil in the coastline of Candelaria, Zambales. Results showed that there was an average of 7.00 meters build up of soil in the coastline of Candelaria, Zambales from 2009 to 2014 while in 2019 it increased with an average of 11.86 meters. Furthermore, in the field data gathered in 2019, there was an increase of 0.66 meters build up of soil from the 2019 historical map data. Moreover, Figure 4 presents the detailed graph of the changes in the coastline of Candelaria, Zambales. It exhibited that 

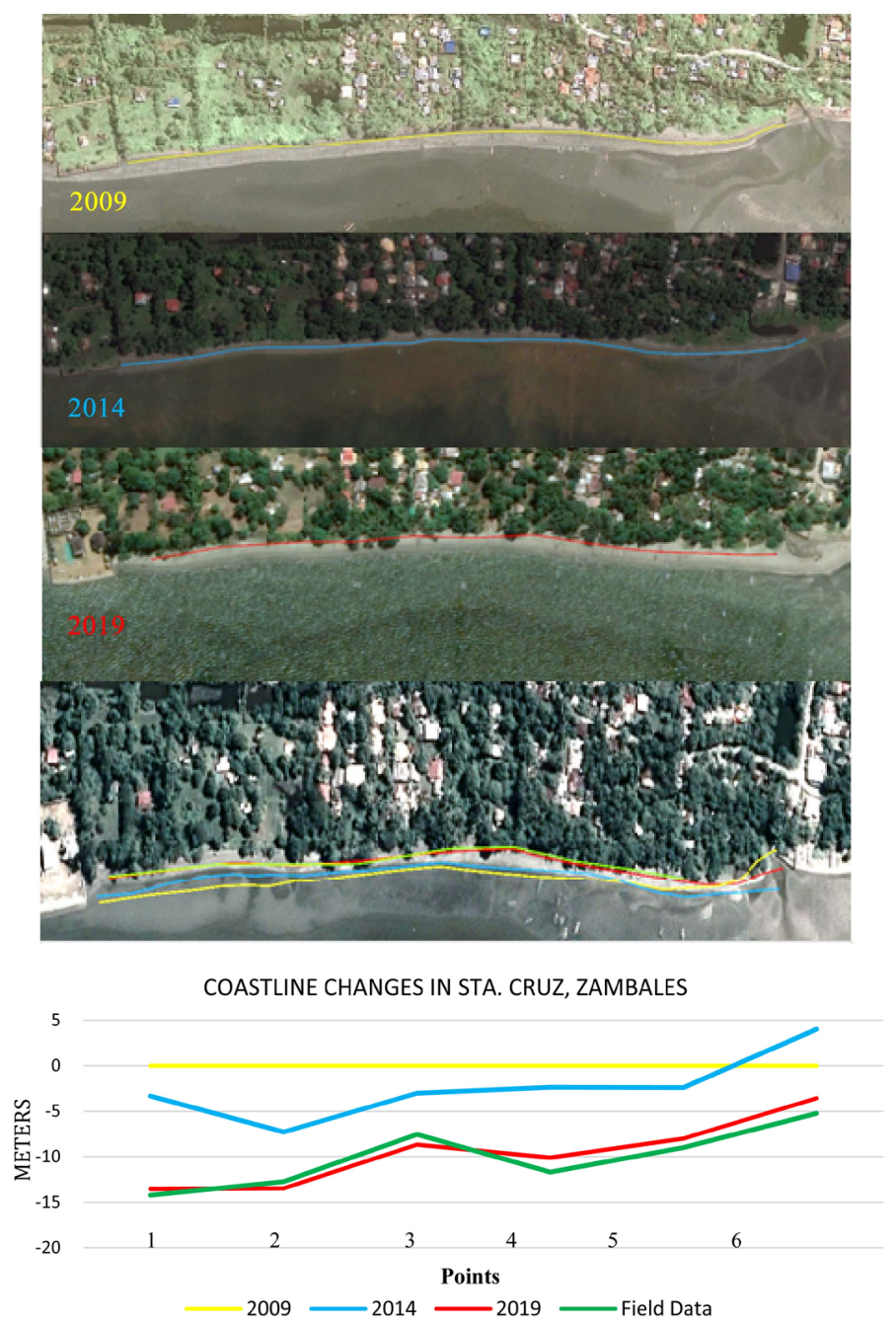

Figure 2. Coastline changes in Sta. Cruz, Zambales.

Table 3. Coastline changes in Candelaria, Zambales.

\begin{tabular}{|c|c|c|c|c|c|c|c|c|c|c|c|c|}
\hline \multirow{2}{*}{$\begin{array}{c}\text { 10-Year } \\
\text { Historical Data }\end{array}$} & \multicolumn{11}{|c|}{ Points (m) } & \multirow{2}{*}{ Average } \\
\hline & 100 & 200 & 300 & 400 & 500 & 600 & 700 & 800 & 900 & 1000 & 1100 & \\
\hline 2009 & 0 & 0 & 0 & 0 & 0 & 0 & 0 & 0 & 0 & 0 & 0 & \\
\hline 2014 & -1.19 & -2.13 & -1.90 & 2.73 & 6.09 & 8 & 6.76 & 5.99 & 5.69 & 6.28 & 2.38 & \\
\hline 2019 & -1.77 & -3.35 & -4.99 & 2.08 & 8.10 & 9.16 & 14.86 & 9.76 & 10.95 & 10.61 & 8.04 & \\
\hline \multirow[t]{3}{*}{$\begin{array}{l}\text { Field Data } \\
\qquad(2019)\end{array}$} & -1.86 & -3.29 & -5.74 & 2.08 & 9 & 9.61 & 16 & 10.36 & 11.94 & 10.61 & 9.70 & \\
\hline & \multicolumn{11}{|c|}{ Points (m) } & \multirow{2}{*}{ Average } \\
\hline & 1200 & 1300 & 1400 & 1500 & 1600 & 1700 & 1800 & 1900 & 2000 & 2100 & 2200 & \\
\hline 2009 & 0 & 0 & 0 & 0 & 0 & 0 & 0 & 0 & 0 & 0 & 0 & 0 \\
\hline 2014 & 3.09 & 5.45 & 5.77 & 6.52 & 12.40 & 10.45 & 19.29 & 17.72 & 11.67 & 13.00 & 10.00 & 7.00 \\
\hline 2019 & 6.69 & 5.41 & 8.61 & 12.45 & 23.23 & 20.18 & 26.85 & 26.21 & 23.94 & 24.68 & 19.15 & 11.86 \\
\hline $\begin{array}{c}\text { Field Data } \\
\text { (2019) }\end{array}$ & 7.37 & 4.06 & 9.36 & 12.76 & 24.60 & 20.85 & 25.25 & 29.00 & 26.00 & 25.00 & 22.87 & 12.52 \\
\hline
\end{tabular}




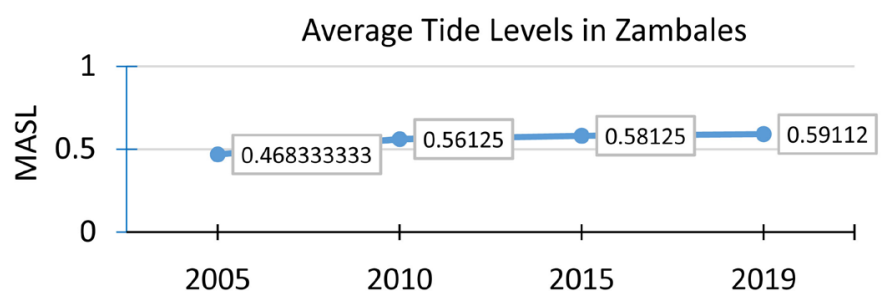

Figure 3. Average tide levels in the four coastal municipalities in Zambales.

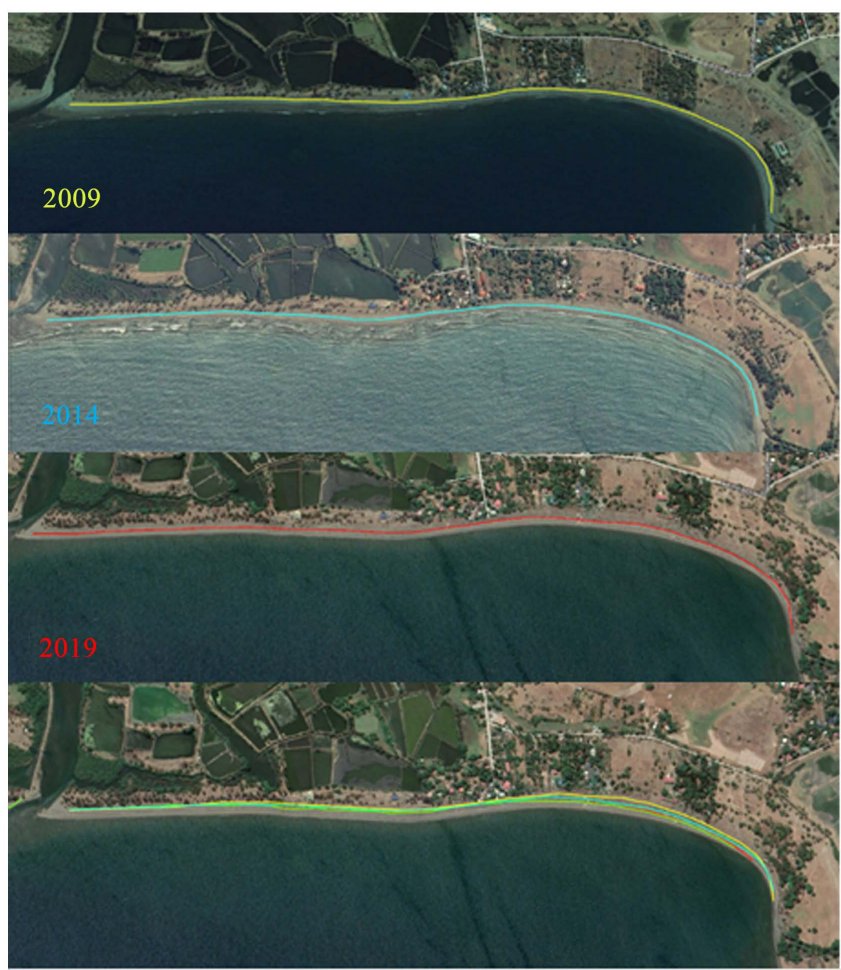

COASTLINE CHANGES IN CANDELARIA, ZAMBALES

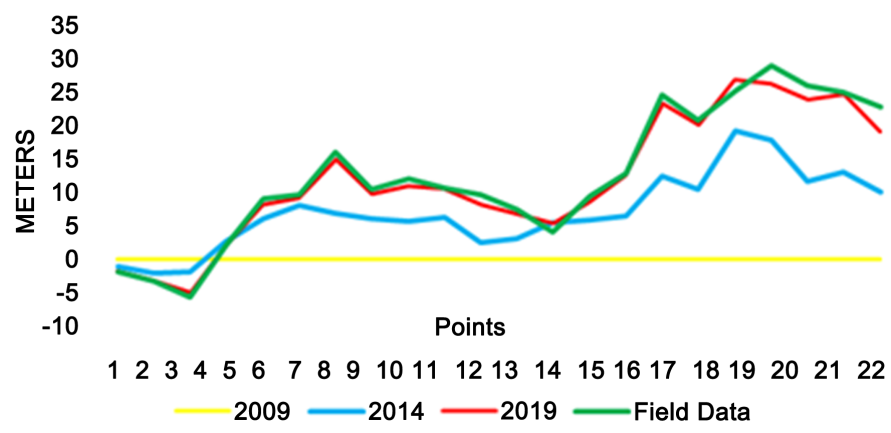

Figure 4. Coastline changes in Candelaria, Zambales.

the highest rate of build up of soil is located at points 15 to point 22 of the coastline. The RMSE was also computed in the coastline of Candelaria, Zambales and results revealed that there was also minimal difference between the field data and the plotted data in Google Earth, with 1.01 meters difference.

Sedimentation and build up of soil in the coastline of Candelaria, Zambales could be due to the sedimentation caused by the river outlets located near the 
coastline and due to its geographical location which is always experiencing strong typhoons. In addition, results of another study showed that some parts of Masinloc, Zambales are experiencing sea level rise and changes in the seascape particularly in Barangay Bani, Candelaria, Zambales (Taguiam \& Quiambao,2016).

Table 4 depicts the changes in the coastline of Masinloc, Zambales. In 2014, historical data indicated that there was an occurrence of sea level rise in Masinloc, Zambales. Results showed that an average of -0.60 meters of sea level rise happened in the 1100 meters shoreline traced particularly in Barangay Bani, Masinloc, Zambales while based on the map in 2019, there was an incident of sedimentation or build up of soil in the coastline, with an average of 4.51 meters. On the other hand, actual field data validation disclosed that there is only 3.56 meters average build up of soil in the area.

Moreover, Figure 5 shows the detailed graph of the changes in the coastline of Masinloc, Zambales and as illustrated the highest rate of build up of soil is located at the point 8 to point 11 of the coastline while points 1 to 7 showed that there was an occurrence of sea level rise. The RMSE computed in the coastline of Masinloc, Zambales had only 0.98 meter difference between the field data and the plotted data in Google Earth.

Sea level rise in Masinloc, Zambales could be due to human induced process such as removing of soil and rock and by natural process such as waves and tidal currents (DENR, 2013) and as a consequence of global warming and climate change (IDCC, 2015). In contrast, the observed sedimentation on the other side could be due to the river outlets which bring a lot of sediments from the mountain in the area because of human activities such as mining, and deforestation.

Table 5 shows the rate on the sedimentation or build up of soil in the coastline of Palauig, Zambales. Results revealed that there was an average of 3.29 meters build up of soil in the coastline of Palauig, Zambales from 2009 to 2014 while in 2019 it had an average of 14.23 meters. Furthermore, the field data gathered in 2019 indicated that there was an average of only 14.11 meters build up of soil.

Figure 6 presents the detailed graph of the changes in the coastline of Palauig, Zambales. It disclosed that the highest rate of buildup of soil is located at point 1 and point 2 of the coastline while points 20 to 21 showed that there was an occurrence of sea level rise. The RMSE was also computed in Palauig and there is

Table 4. Coastline changes in Masinloc, Zambales.

\begin{tabular}{ccccccccccccc}
\hline \multirow{11}{*}{$\begin{array}{c}\text { 10-Year } \\
\text { Historical Data }\end{array}$} & \multicolumn{10}{c}{ Points (m) } & Average \\
\cline { 2 - 8 } & 100 & 200 & 300 & 400 & 500 & 600 & 700 & 800 & 900 & 1000 & 1100 & \\
\hline 2009 & 0 & 0 & 0 & 0 & 0 & 0 & 0 & 0 & 0 & 0 & 0 & 0 \\
2014 & -31.14 & -14 & -4.00 & 5.00 & -1.68 & -2.11 & -3.95 & -.71 & 5.74 & 18.16 & 22.00 & -0.60 \\
2019 & -10.75 & -2.01 & -0.27 & -1.44 & -5.61 & -6.97 & -2.68 & 4.01 & 13.37 & 29.33 & 32.65 & 4.51 \\
Field Data (2019) & -8.80 & -1.44 & -0.27 & -2.78 & -5.82 & -6.68 & -4.00 & 2.00 & 2.66 & 31.00 & 33.33 & 3.56 \\
\hline
\end{tabular}



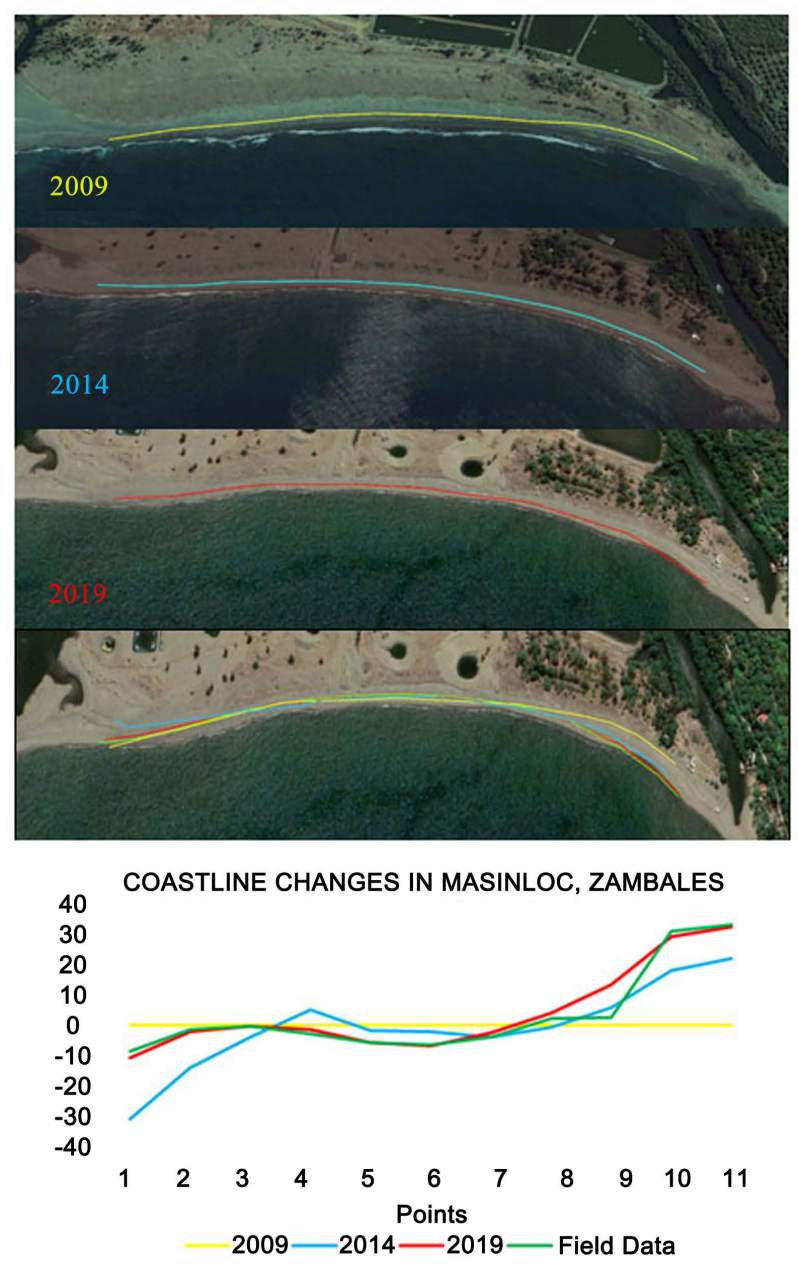

Figure 5. Coastline changes in Masinloc, Zambales.

Table 5. Coastline changes in Palauig, Zambales.

\begin{tabular}{|c|c|c|c|c|c|c|c|c|c|c|c|c|}
\hline \multirow{2}{*}{$\begin{array}{c}10-\text { Year } \\
\text { Historical Data }\end{array}$} & \multicolumn{11}{|c|}{ Points (m) } & \multirow{2}{*}{ Average } \\
\hline & 100 & 200 & 300 & 400 & 500 & 600 & 700 & 800 & 900 & 1000 & 1100 & \\
\hline 2009 & 0 & 0 & 0 & 0 & 0 & 0 & 0 & 0 & 0 & 0 & 0 & \\
\hline 2014 & 2.32 & 8.89 & 3.74 & 1.38 & 3.79 & 3.68 & 6.18 & 5.85 & 4.17 & 8.58 & 5.75 & \\
\hline 2019 & 26.21 & 18.56 & 13.97 & 16.24 & 14.25 & 16.43 & 15.65 & 15.12 & 8.80 & 11.60 & 11.64 & \\
\hline \multirow[t]{3}{*}{$\begin{array}{l}\text { Field Data } \\
\text { (2019) }\end{array}$} & 26.21 & 18.56 & 12.50 & 17.48 & 14.96 & 17 & 16.8 & 12.30 & 6.75 & 10.46 & 12.50 & \\
\hline & \multicolumn{11}{|c|}{ Points (m) } & \\
\hline & 1200 & 1300 & 1400 & 1500 & 1600 & 1700 & 1800 & 1900 & 2000 & 2100 & & \\
\hline 2009 & 0 & 0 & 0 & 0 & 0 & 0 & 0 & 0 & 0 & 0 & & 0 \\
\hline 2014 & 8.76 & 1.78 & 2.70 & 4.44 & 0 & 5.94 & 5 & 1 & -4.12 & -10.69 & & 3.29 \\
\hline 2019 & 15.48 & 16.28 & 12.38 & 17.96 & 9.20 & 18.11 & 12.38 & 14.56 & 12 & 2.18 & & 14.23 \\
\hline $\begin{array}{l}\text { Field Data } \\
\text { (2019) }\end{array}$ & 19 & 17.04 & 12.38 & 14 & 9 & 15 & 14 & 16.6 & 12.58 & 1.2 & & 14.11 \\
\hline
\end{tabular}



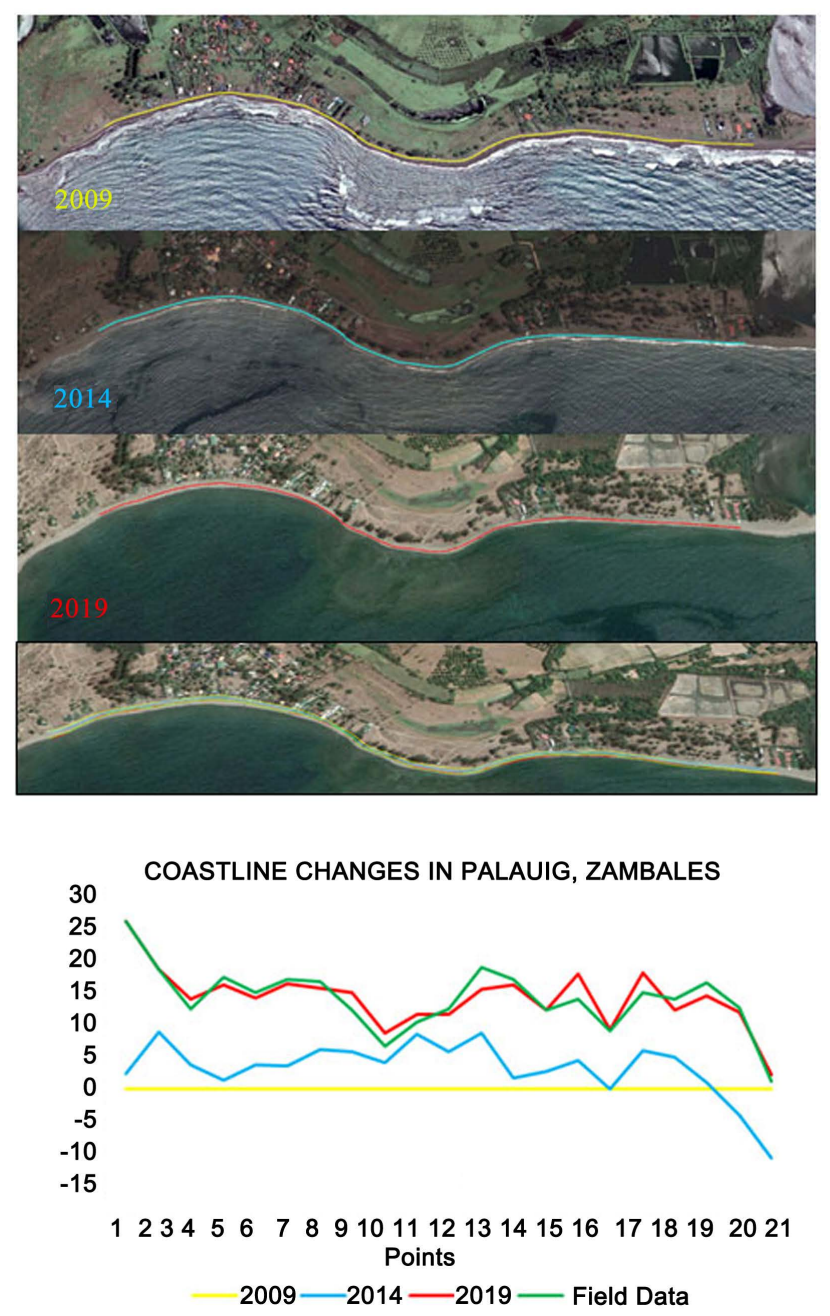

Figure 6. Coastline changes in Palauig, Zambales.

only a minimal difference of 1.37 meters between the field data and the plotted data in Google Earth which is also low. But, in comparison to the RMSE of other coastal municipalities, the RMSE of Palauig has the highest value.

Sedimentation and build up of soil in the coastline of Palauig, Zambales could be due to the sedimentation caused by the rivers outlets located near the coastline which bring sediments during torrential rains and flooding events. Moreover, the built up areas with high density of population and household near the area could also contribute to the sedimentation in the area.

\section{Climate Change Vulnerability and Disaster Risk Assessment}

\subsection{Vulnerability Assessment}

Vulnerability is defined as "the characteristics of a person or group and their situation that influences their capacity to anticipate, cope with, resist, and recover from the impact of a hazardous event". Vulnerability represents the susceptibility of a given population to harmful effects from exposure to hazardous 
events. It directly affects disaster preparation, response, and recovery. Hazardous event can directly or indirectly affect the health status of an individual or a population. Hazardous event can result in a detrimental impact to individual and/or their asset (Du et al., 2015).

Vulnerability assessment is the process of identifying negative impacts of threats from potential hazards to vulnerabilities in a system. Satellite images were also generated and overlayed with the hazards to better assess the vulnerability of area through satellite images processing and specifically identify areas that were affected by these particular hazards.

\subsubsection{Flood}

The flood vulnerability map of Sta. Cruz is shown in Figure 7(a). Sta. Cruz, Zambales has 24 barangays. Results revealed that among the 24 barangays in the municipality only Barangay Babuyan (0.47) is the least vulnerable to flood due to its high elevation while Barangays Bolitoc (0.71) and Lipay (0.72) are the most vulnerable to flood because their agriculture, coastal and marine resources are highly sensitive to flooding. The rest of barangays have moderate vulnerability to flood.

The flood vulnerability map of Candelaria is displayed in Figure 7(b). Results indicated that there is moderate flooding in the area which could be due to some inundation of structures and roads near the river and creeks. However, the municipality has the ability to adapt to flooding due to the presence of updated maps of flood prone areas and coastal habitats that are at risk. They also have access to flood forecasting information and early warning system. Moreover, the forest part of Barangays Uacon, Malimanga, Malabon, Pamibian, Taposo and Lauis have low vulnerability to flood due to high elevation of these barangays for they are located in the forest or mountainous parts of the municipality.

Figure 7 (c) presents the flood vulnerability map of Masinloc . Results revealed that Barangays San Salvador (0.50), San Lorenzo (0.46) and Taltal (0.49) were found to be low vulnerable to flooding while the rest of the barangays have moderate vulnerability to flooding. The main cause of flooding in the municipality occurs when high tide combines with high velocity of the river that traverses the municipality. However, Masinloc has the flood rescue equipment for adaptation to flooding. The municipality has updated maps and established radio communication in every barangay for faster and efficient coordination. The condition and accessibility of infrastructure, accessibility of health care, human and social capital (the skills, knowledge, experience, and social cohesion of a community), and other institutional resources all contribute to the timeliness and effectiveness of adaptive capacity.

Figure 7 (d) shows the flood vulnerability map of Palauig, Zambales. There are 19 barangays in Palauig and 10 of these barangays were found to be moderately vulnerable to flooding which include Barangays Bulawen (0.63), Cauyan (0.61), Libaba (0.69), Magalawa (0.58), Pangolinan (0.64), Salaza (0.57), San Juan (0.70), San Vicente (0.69) Santo Niño (0.67) and West Poblacion (0.70). High 


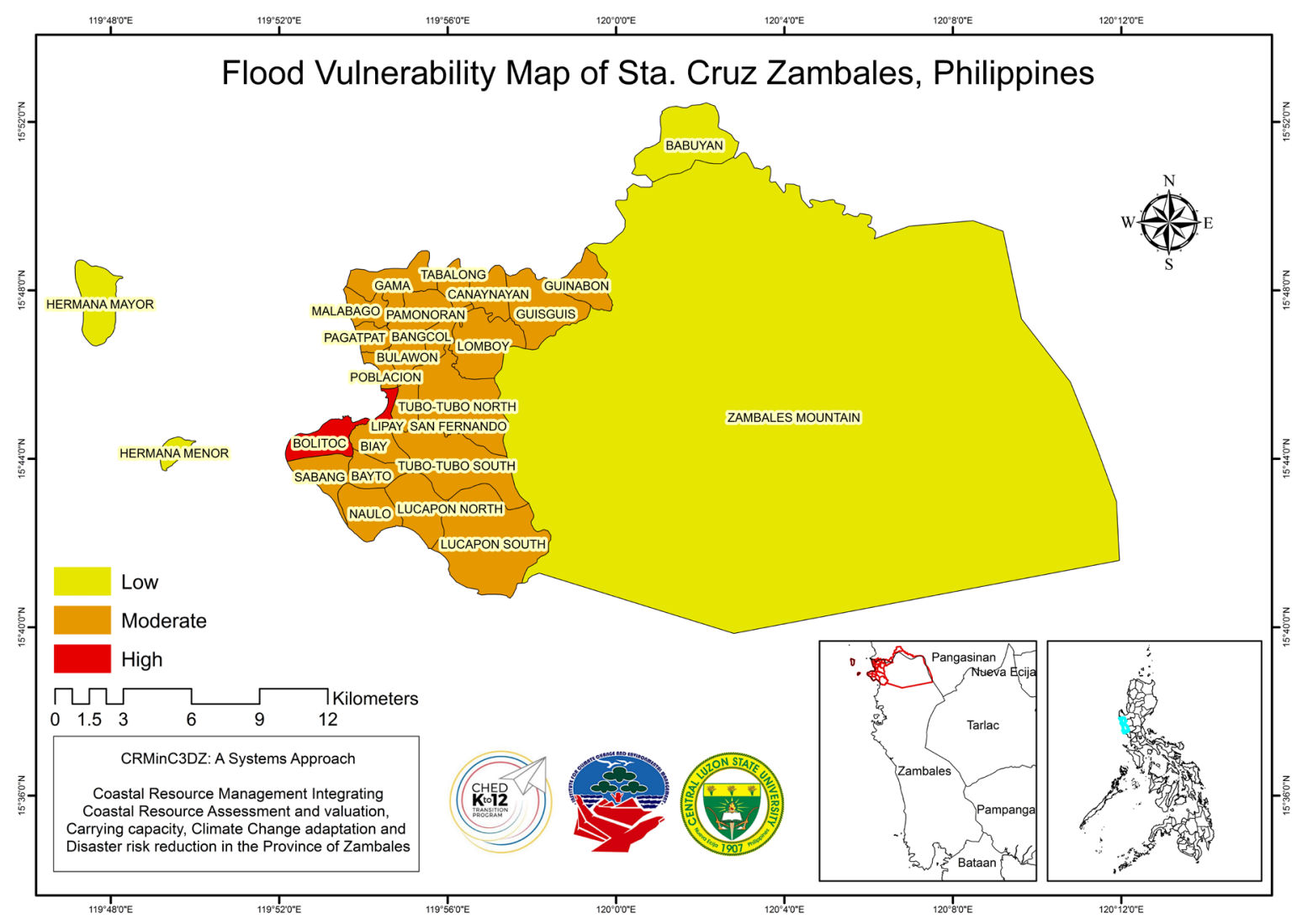

(a)

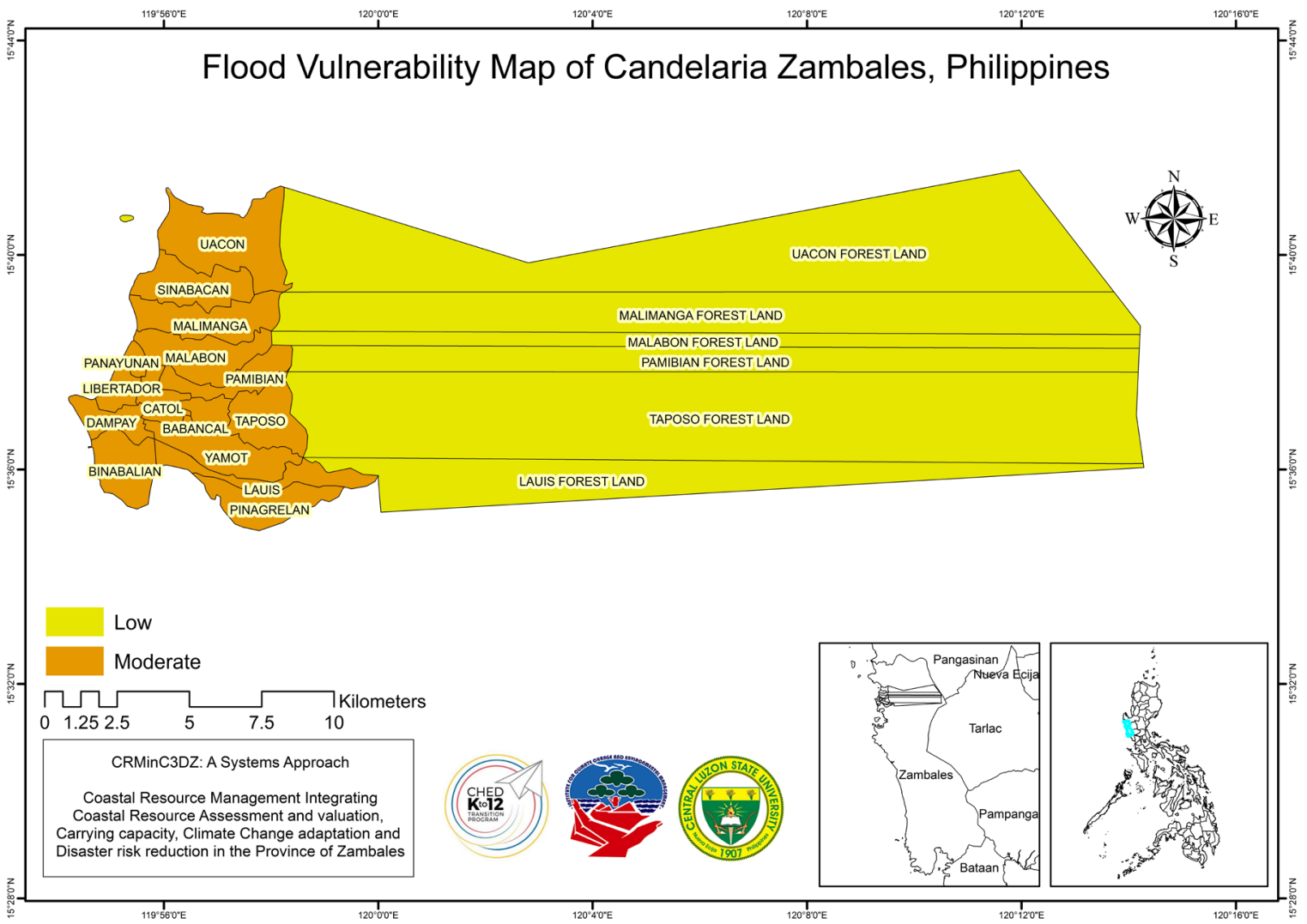

(b) 


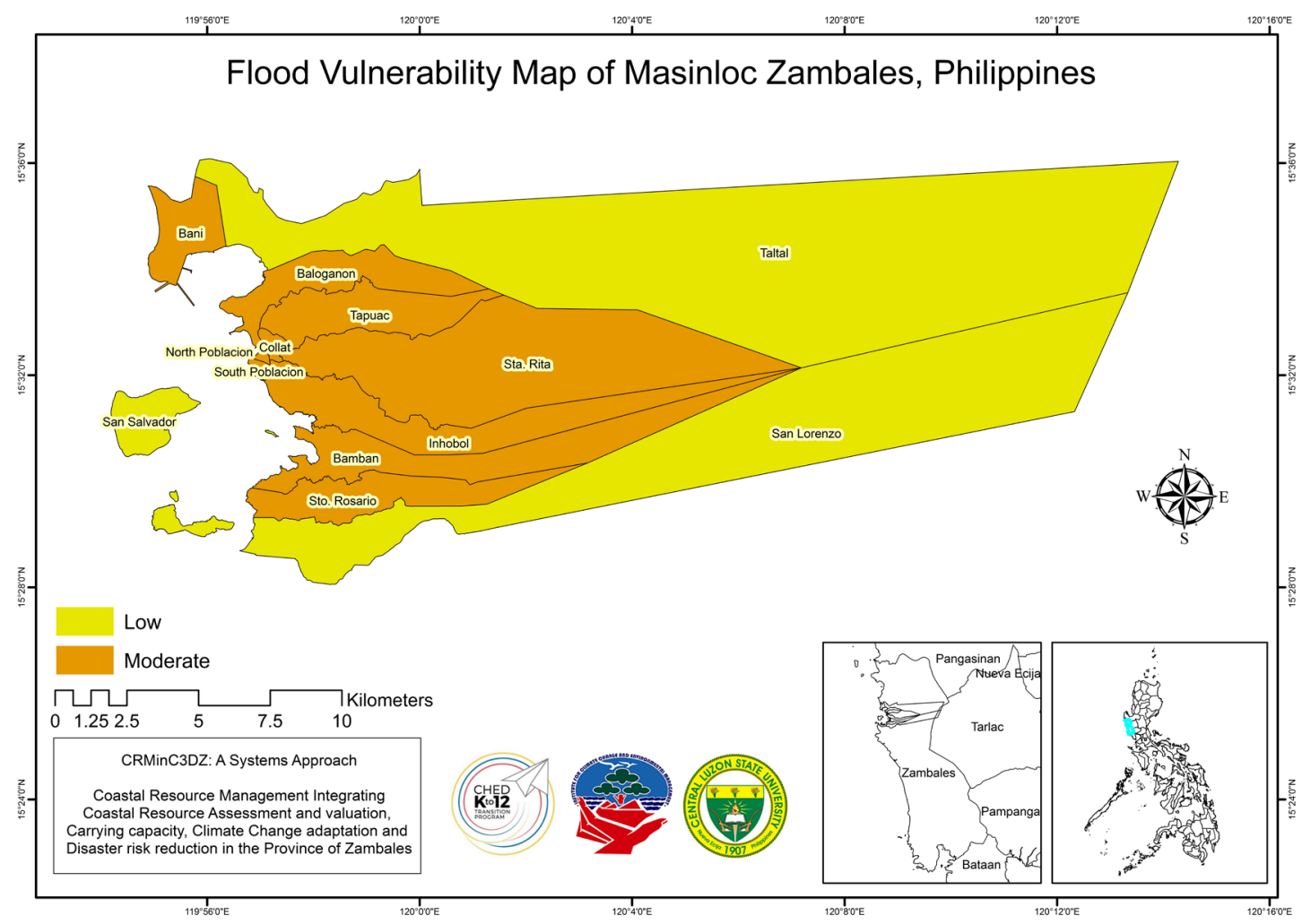

(c)

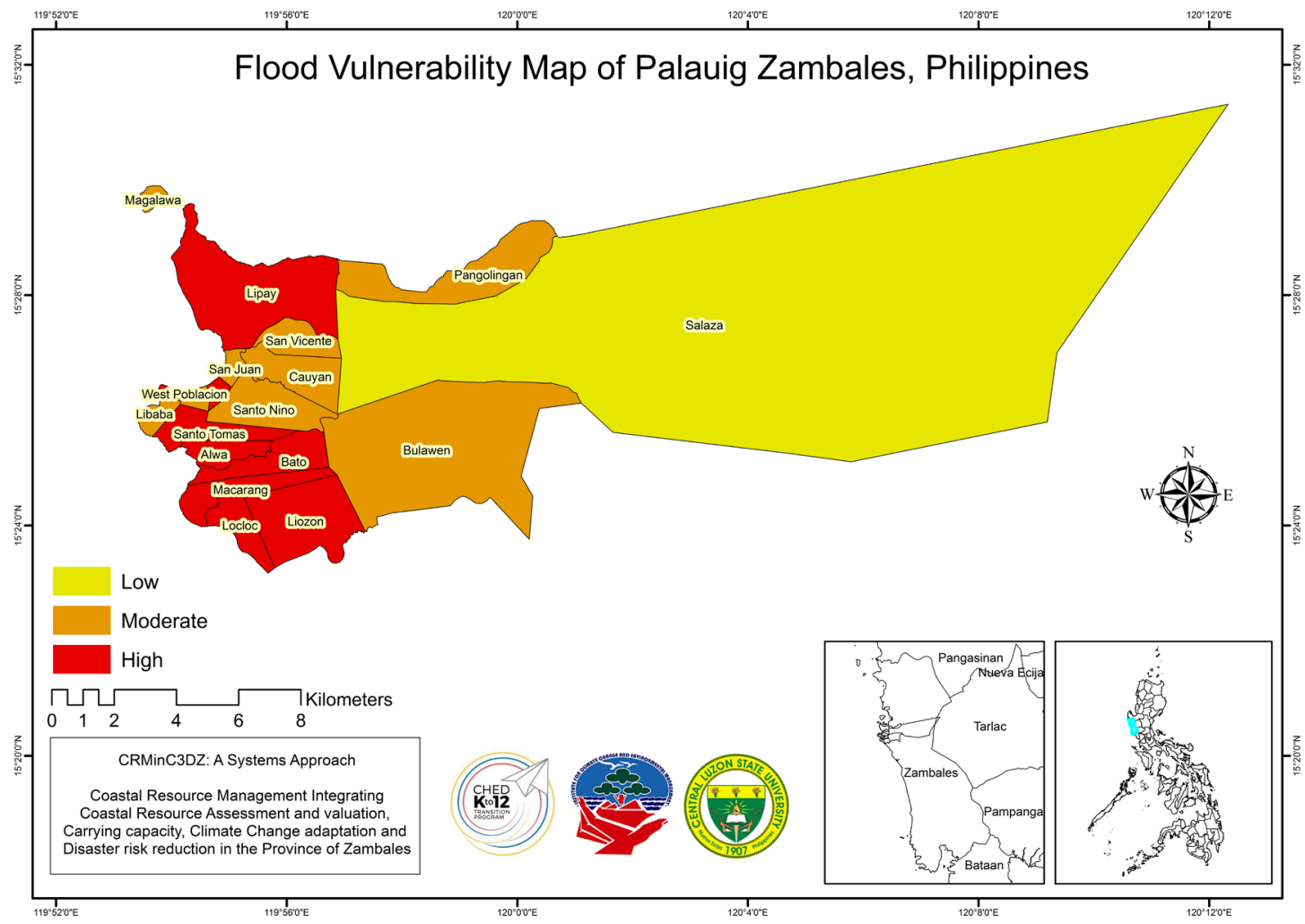

(d)

Figure 7. (a) Flood vulnerability map of Sta Cruz, Zambales; (b) Flood vulnerability map of Candelaria, Zambales; (c) Flood vulnerability map of Masinloc, Zambales; (d) Flood vulnerability map of Paluig, Zambales. 
percentage of population who are dependent on agriculture and many settlement houses in some barangays cause high vulnerability to flooding because of the dynamic patterns of land use. Moreover, adaptive capacity at the local level remains limited. Based on secondary data gathered in the municipality maps of flood prone areas were outdated and maps or data about coastal habitats that are at risk were lacking. Moreover, results on primary data gathering revealed that the municipality has poor access to flood early warning system and lack of areas for relocation for coastal communities who are at risk during flood incidents. Therefore, capacity building for those vulnerable communities should be prioritized by the decision maker.

\subsubsection{Landslide}

Figure 8(a) shows the landslide vulnerability map of Sta. Cruz, Zambales. Barangays Babuyan (0.61), Tubo-tubo South (0.60) Lucapon South (0.64) and Zambales Mountain (0.60) were moderately vulnerable to landslide. These barangays have steep slopes and experienced the most frequent heavy rainfall. The rest of the barangays have low vulnerability to landslide for these barangays are located in low-lying areas.

Figure 8 (b) presents the landslide vulnerability map of Candelaria. The municipality is situated beside Sta. Cruz, Zambales. Results revealed that nine (9) barangays were moderately vulnerable to landslide. These are Barangays Babancal (0.51), Lauis (0.55), Malimanga (0.57), Pamibian (0.54), Sinabacan (0.56), Taposo (0.59), Uacon (0.57) and Yamot (0.54) while the rest of the barangays in the municipality had low vulnerability to landslide. However, it can be observed in Figure 8(b) that the forest part of the area including Uacon, Malimanga, Malabon, Pamibian, Taposo and Lauis are highly vulnerable to landslide due to steep slopes and presence of human activities such as mining and building construction.

The landslide vulnerability map of Masinloc, Zambales is shown in Figure 8 (c). Only Barangay Taltal had moderate vulnerability to landslide due to higher values obtained for sensitivity and exposure to landslide with 0.72 and 0.53 , respectively while the rest of the barangays had low vulnerability to landslide. Masinloc has low vulnerability to landslide because the agricultural areas, houses and residents are very far from the mountains which are the landslide prone areas. Moreover, there are no construction/extraction activities and charcoal making activities observed in the forest of Masinloc and in fact, its disaster plans are well prepared and coordinated throughout the municipality.

Landslide vulnerability map of Palauig is depicted in Figure 8(d). Results disclosed that majority of the barangays had low vulnerability to landslide. These barangays are Barangays Alwa (0.48), Bato (0.49), East Poblacion (0.47), Garreta (0.47), Libaba (0.48), Locloc (0.47), Macarang (0.47), Magalawa (0.48), San Juan (0.50), Santo Tomas (0.49) and West Poblacion (0.49). The rest of the barangays had moderate vulnerability to landslide due to higher elevation and located on or near the mountainous parts of the municipality. Moreover, human activities 


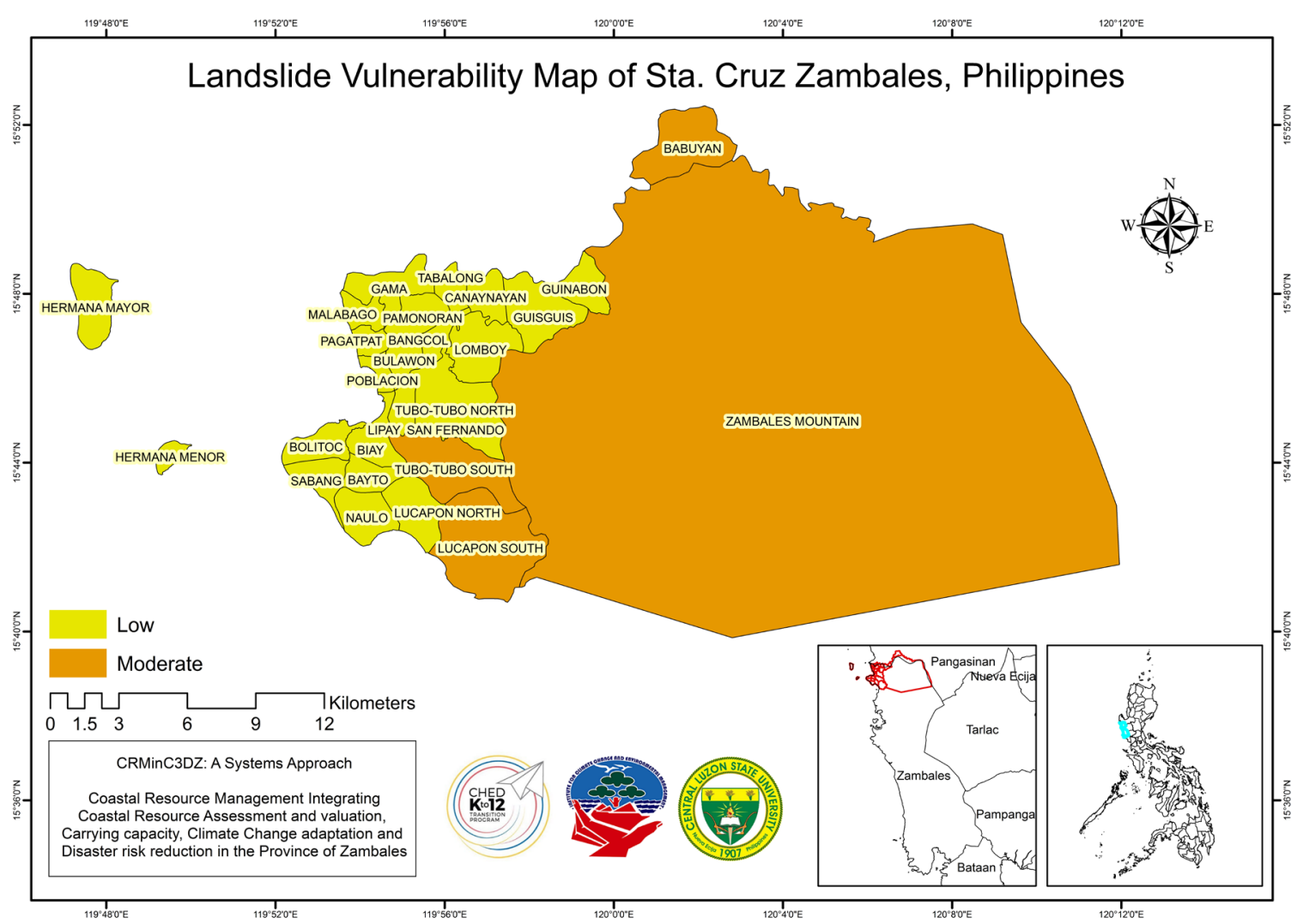

(a)

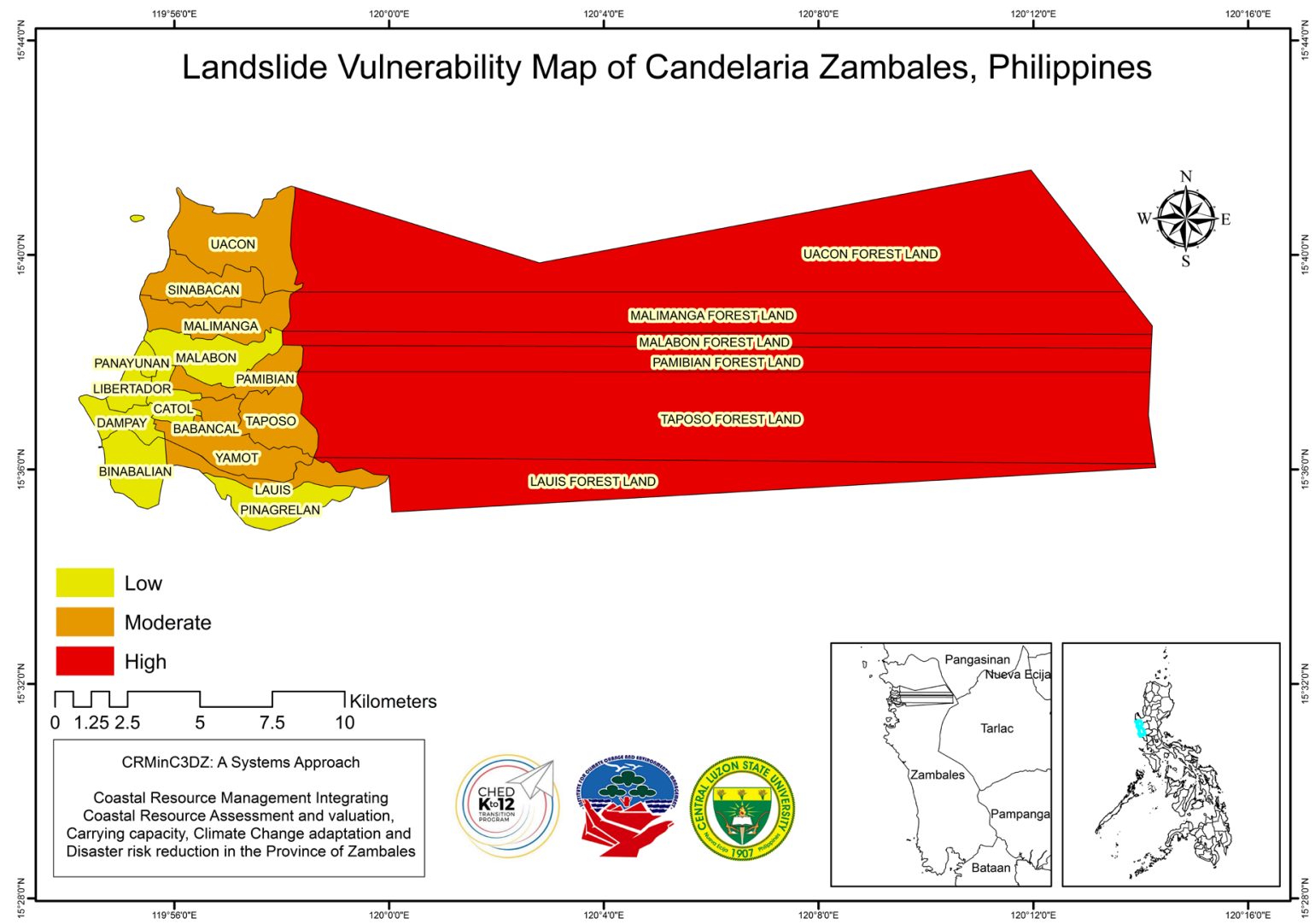

(b) 


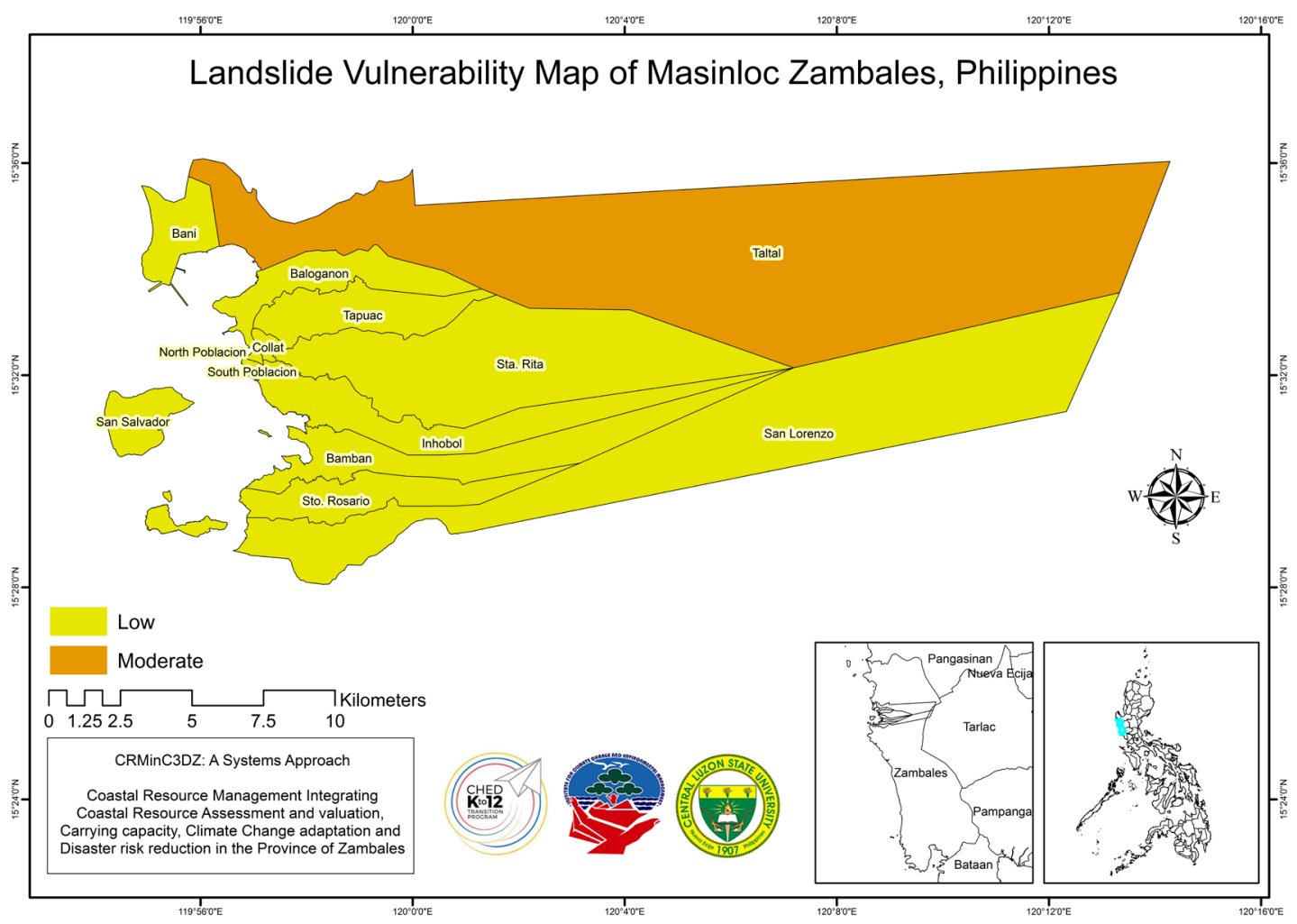

(c)

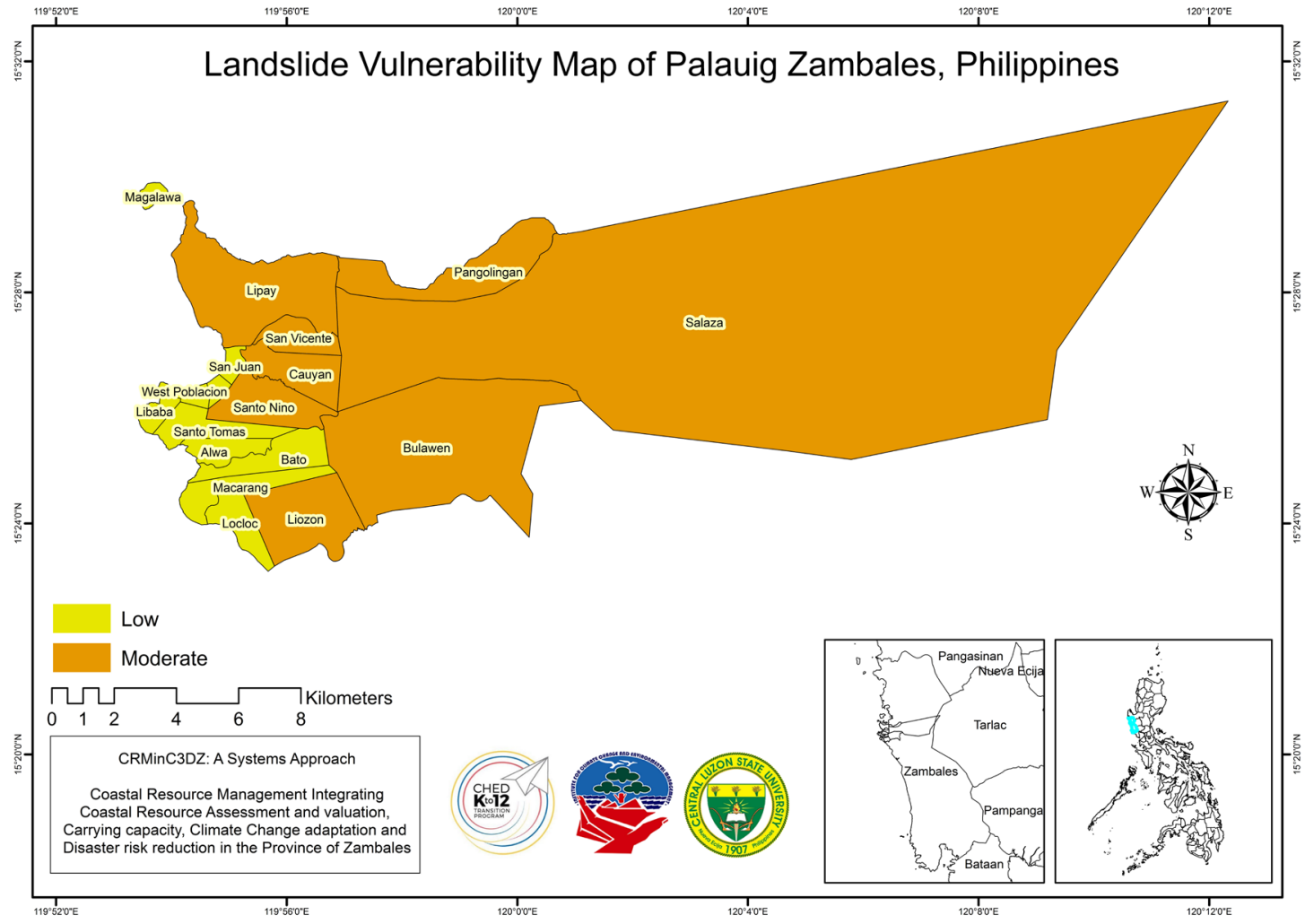

(d)

Figure 8. (a) Landslide vulnerability map of Sta Cruz, Zambales; (b) Landslide vulnerability map of Candelaria, Zambales; (c) Landslide vulnerability map of Masinloc, Zambales; (d) Landslide vulnerability map of Palauig, Zambales. 
such as building and road construction and clearing of vegetation in the mountain expose the land which lead to landslide in the area. However, the positive coping strategies of the indigenous people living at the foot of the mountain to deal with landslides included good farming methods, support from government, livelihood diversification and using indigenous knowledge in weather forecasting and preparedness.

\subsubsection{Storm Surge}

Figure 9(a) shows the storm surge vulnerability map of Sta. Cruz, Zambales. The map indicated that only the coastal barangays in Sta. Cruz are affected by storm surge. Results indicated that Barangays Gama (0.73), Lipay (0.84), Lucapon North (0.74), Lucapon South (0.80), Malabago (0.84), Naulo (0.82), Pagatpat (0.83), and Poblacion (0.87) were highly vulnerable to storm surge. These barangays have only few natural barriers like seagrass, mangroves and coral reefs that could protect them from storm surge. However, Barangay Biay (0.53), Bolitoc (0.64) and Sabang (0.68) were moderately vulnerable to storm surge while the non-coastal barangays of Sta. Cruz had low vulnerability to storm surge.

The Candelaria storm surge vulnerability map is displayed in Figure 9(b). Most of the barangays in Candelaria are situated near the coastal area. Barangays Dampay (0.75), Libertador (0.75), Malimanga (0.81) Panayonan (0.75) Sinabacan (0.81) and Uacon (0.78) were found to be highly vulnerable to storm surge. Two barangays had moderate vulnerability to storm surge and these are Barangays Binabalian (0.63) and Uacon (0.70). All the non-coastal barangays were found to be low vulnerable to storm surge. The area with high vulnerability to storm surge was observed to have lack of mangroves in the coastal area that serve as barrier for storm surge. The rehabilitation of mangroves was focused only in the Uacon Lake.

The municipality of Masinloc, Zambales was moderately vulnerable to storm surge as shown in Figure 9(c) with an average index score of 0.58. Only Barangay Bani was found to be highly vulnerable to storm surge with an index score of 0.73 because Masinloc coal-fired power plant that causes an environmental problem to the municipality is located in this barangay and also devoid of mangrove ecosystems. However, Barangays Santa Rita (0.38), Santo Rosario (0.44) and Tapuac (0.48) were found to be low vulnerable to storm surge. Barangays Sta. Rita and Tapuac are not coastal barangays while most settlement houses in Barangay Sto. Rosario is far away from the shore. Almost all barangays in Masinloc are coastal barangays in other words villages located near the coastal and low-lying areas are more vulnerable to storm surges. However, Masinloc also has disaster preparedness program and plan for this kind of hazard.

Storm surge vulnerability map of Palauig, Zambales can be seen in Figure 9(d). Eight (8) barangays in Palauig were highly vulnerable to storm surge and these are East Poblacion (0.89), Garreta (0.79), Lipay (0.76), Locloc (0.76), Macarang (0.75), Magalawa (0.76), San Juan (0.89) and West Poblacion (0.89) due to low adaptive capacity of the municipality. The municipality is not equip 


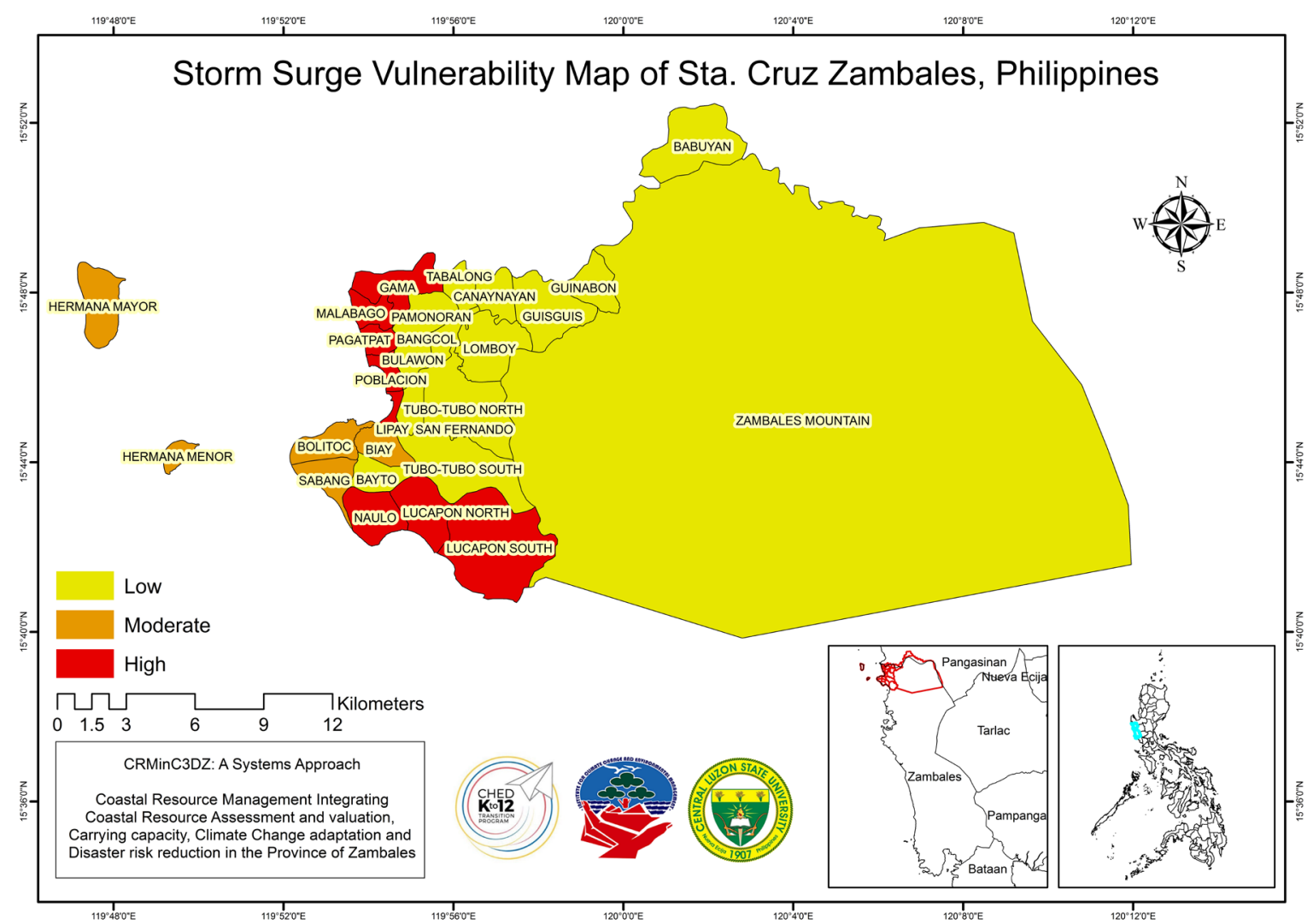

(a)

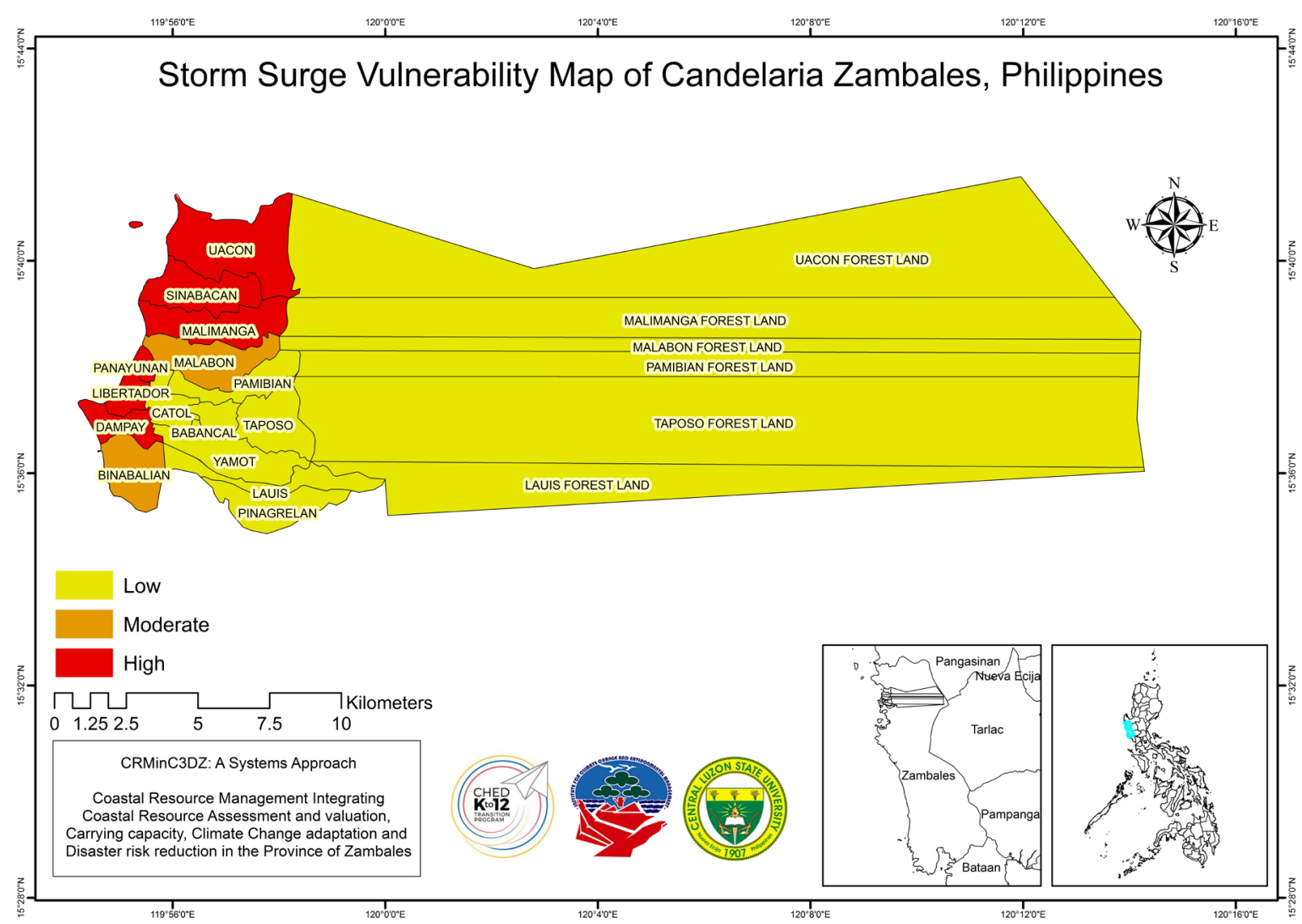

(b) 


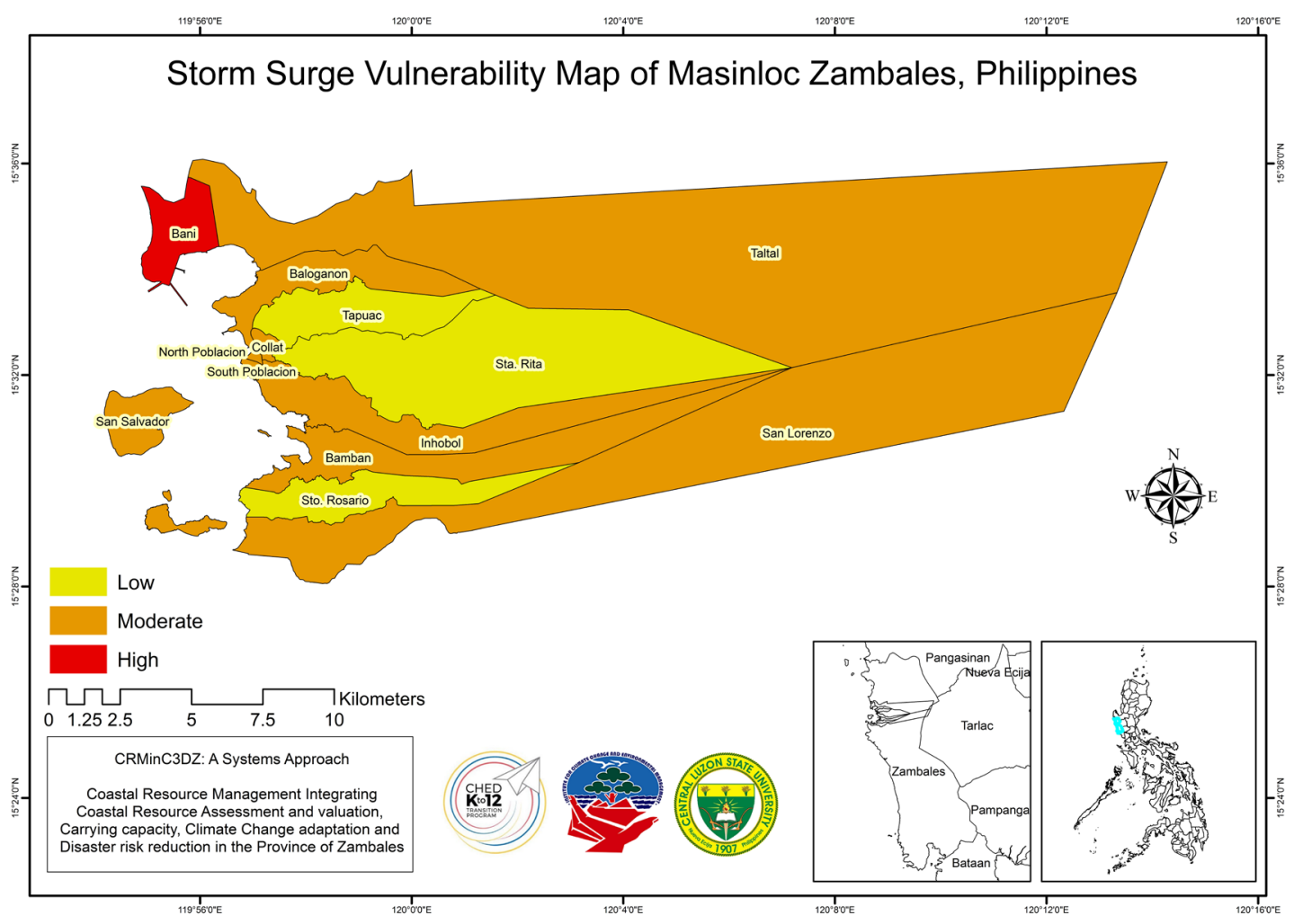

(c)

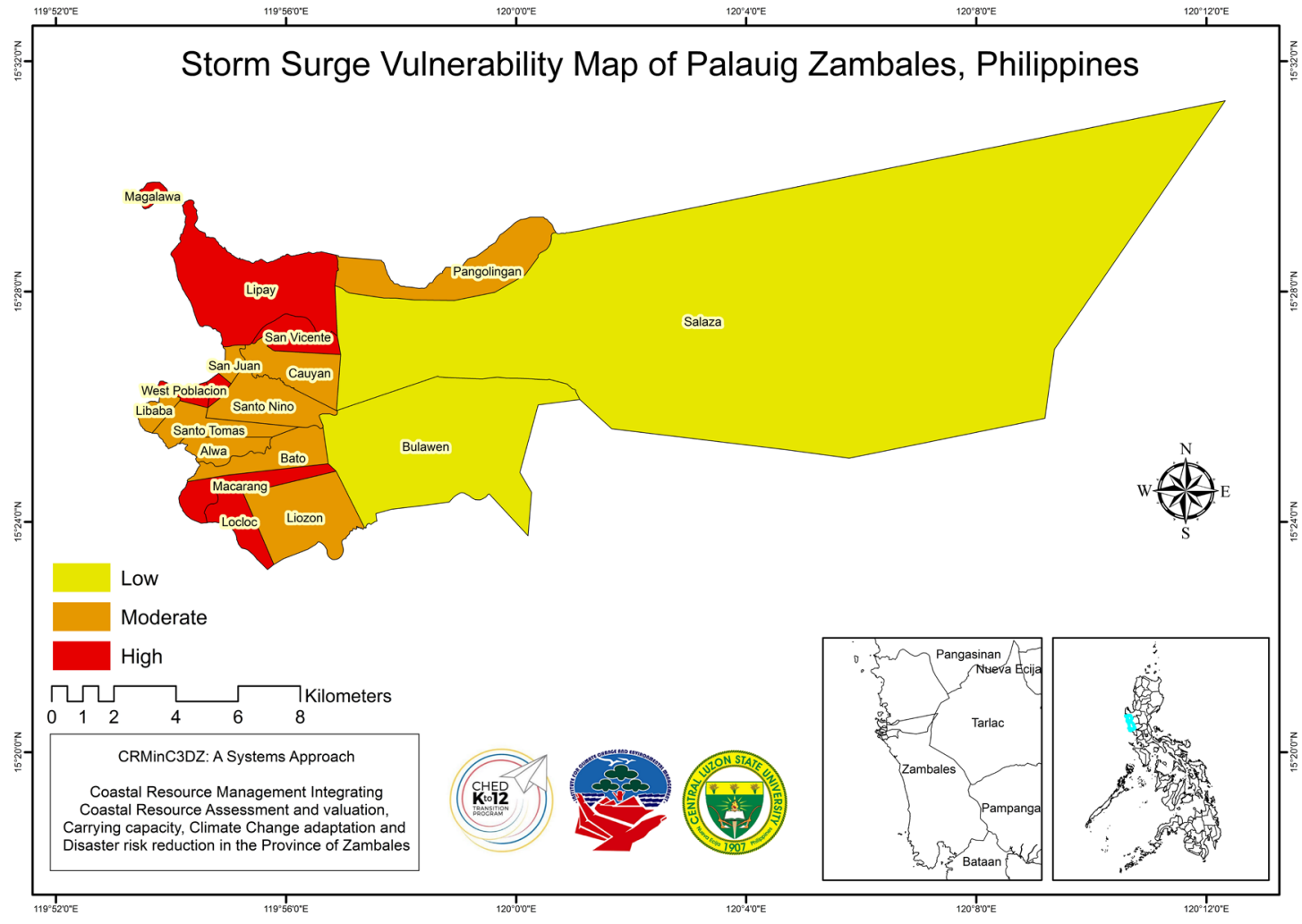

(d)

Figure 9. (a) Storm surge vulnerability map of Sta Cruz, Zambales; (b) Storm surge vulnerability map of Candelaria, Zambales; (c) Storm surge vulnerability map of Masinloc, Zambales; (d) Storm surge vulnerability map of Palauig, Zambales. 
with early warning systems and it has weak social network to help them cope with disasters. Moreover, natural barriers like mangrove ecosystem in the municipality are not sufficient enough to protect them to this kind of hazard. In addition, the municipality's exposure to storm surge index score was high. The municipality is more sensitive in terms of extent of settlements and population affected, agricultural lands affected and extent of beaches and costal shores damaged by typhoons.

\subsection{Disaster Risk Assessment}

Disaster risk is not just about the likelihood and severity of the hazard event but also about what is exposed to that hazard and how vulnerable that exposure is. Disaster risk assessment is a process to determine the nature and extent of such risk, by analyzing hazards and evaluating existing conditions of vulnerability that together could potentially harm and expose the people, property, services, livelihoods and the environment (UNISDR, 2017).

Risk is complicated, but understanding is vital to the proper protection of society and environment. Risk assessment is a means not only to understand the risks that society (or a family or business) faces, with their potential probabilities and impacts, but also to provide a framework to assess their risk to climate change related hazards at the local level, in order to reduce potential costs, to develop risk reduction strategies to determine the effectiveness of disaster risk management, risk prevention and/or risk mitigation.

Disaster risk assessment was done to identify the areas that were affected by different kinds of disasters and to classify the percentage affected in each of the barangays in the selected municipalities.

\subsubsection{Flood}

Floods are the most common natural disaster in the Philippines. Floods in Zambales may result from heavy rain, high tides in coastal areas, overflows of river and dams and even man-made floods. Man-made floods can cause or trigger the natural disaster by deforestation, pollution and rapid urbanization in the area (Greentumble, 2016).

Figure 10(a) shows the flood disaster risk map of the municipality of Sta. Cruz, Zambales. Most of the barangays were affected with low to moderate flooding for they are located in low-lying areas and near two major river systems namely Nayom River and Alunsaud River. Barangays which could experience moderate flooding are Babuyan, Bangcol, Biay, Bolitoc, Bulawon, Canynayn, Gama, Guinabon, Guisguis, Lipay, Lomboy, Lucapon North, Lucapon South, Malabago, Pagatpat, Poblacion, San Fernando, Tabalong, Tubo-tubo North, Naulo, Sabang and Tubo-tubo South. Only Barangay Babuyan and the two islands (Hermana Menor and Hermana Mayor) may experience low flooding.

Figure 10(b) illustrates the flood disaster risk map of the municipality of Candelaria. Result showed that the municipality may experience moderate flooding with an estimated area of 4511 ha. (12.97\%). Rising of water level in the 


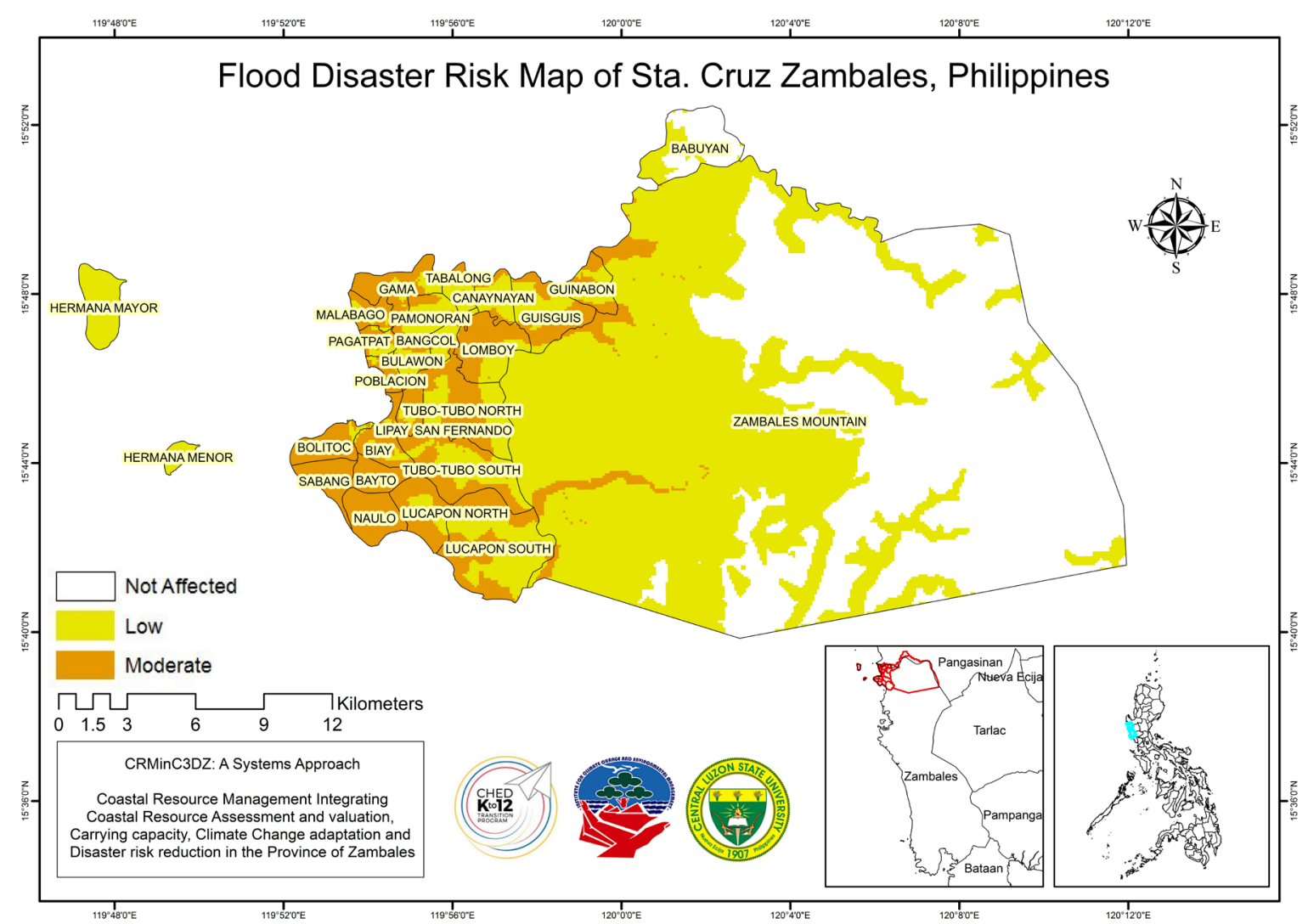

(a)

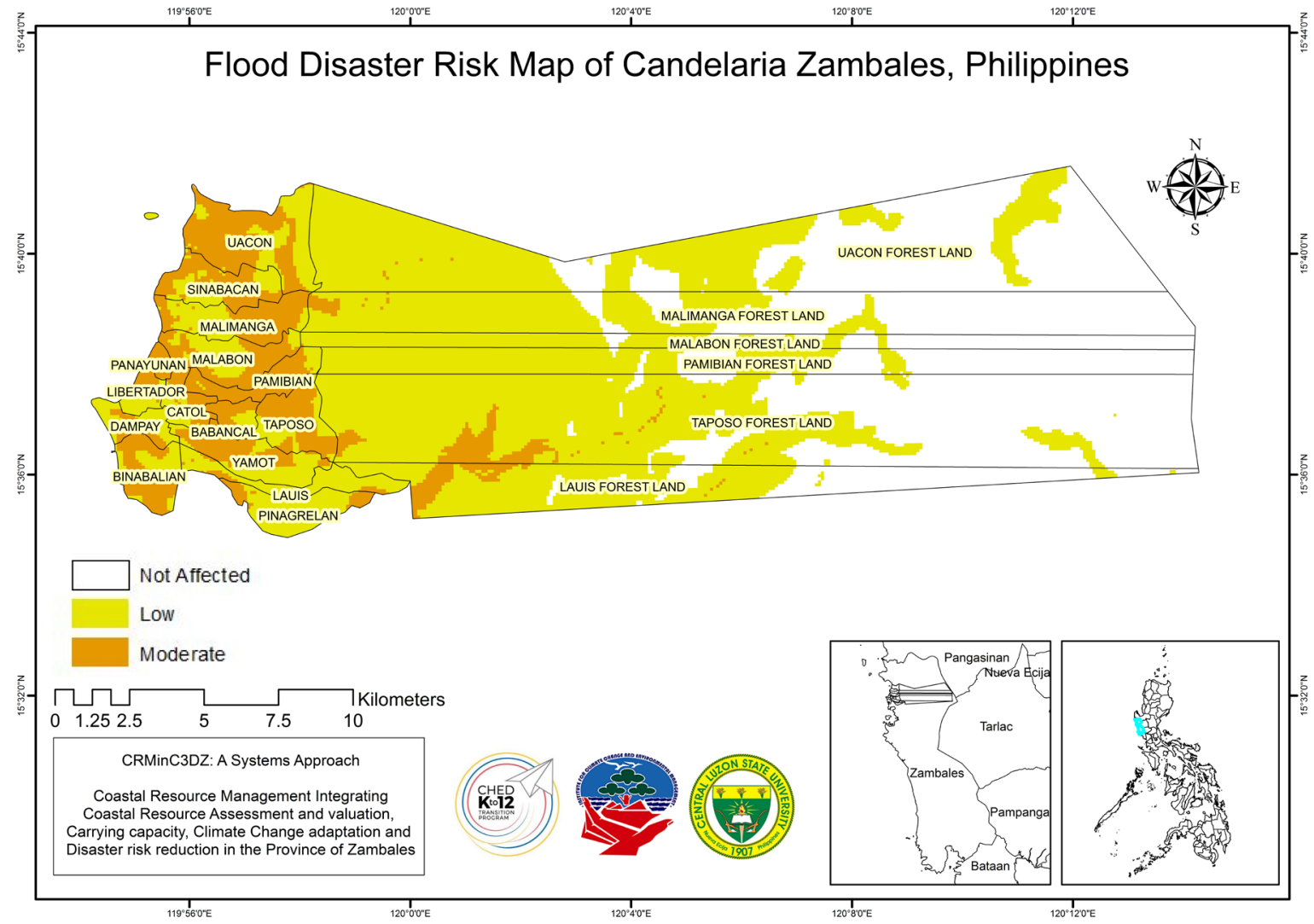

(b) 


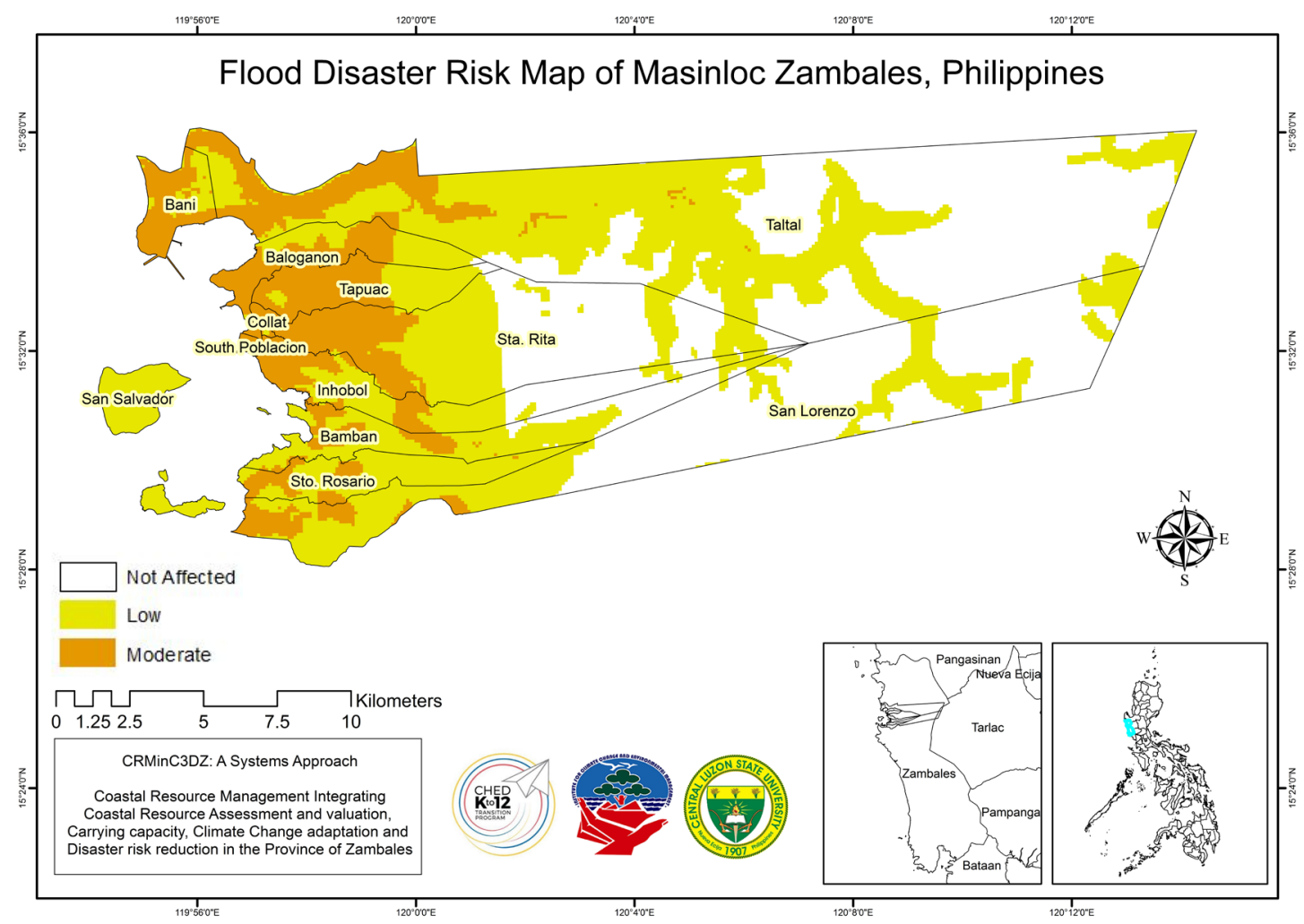

(c)

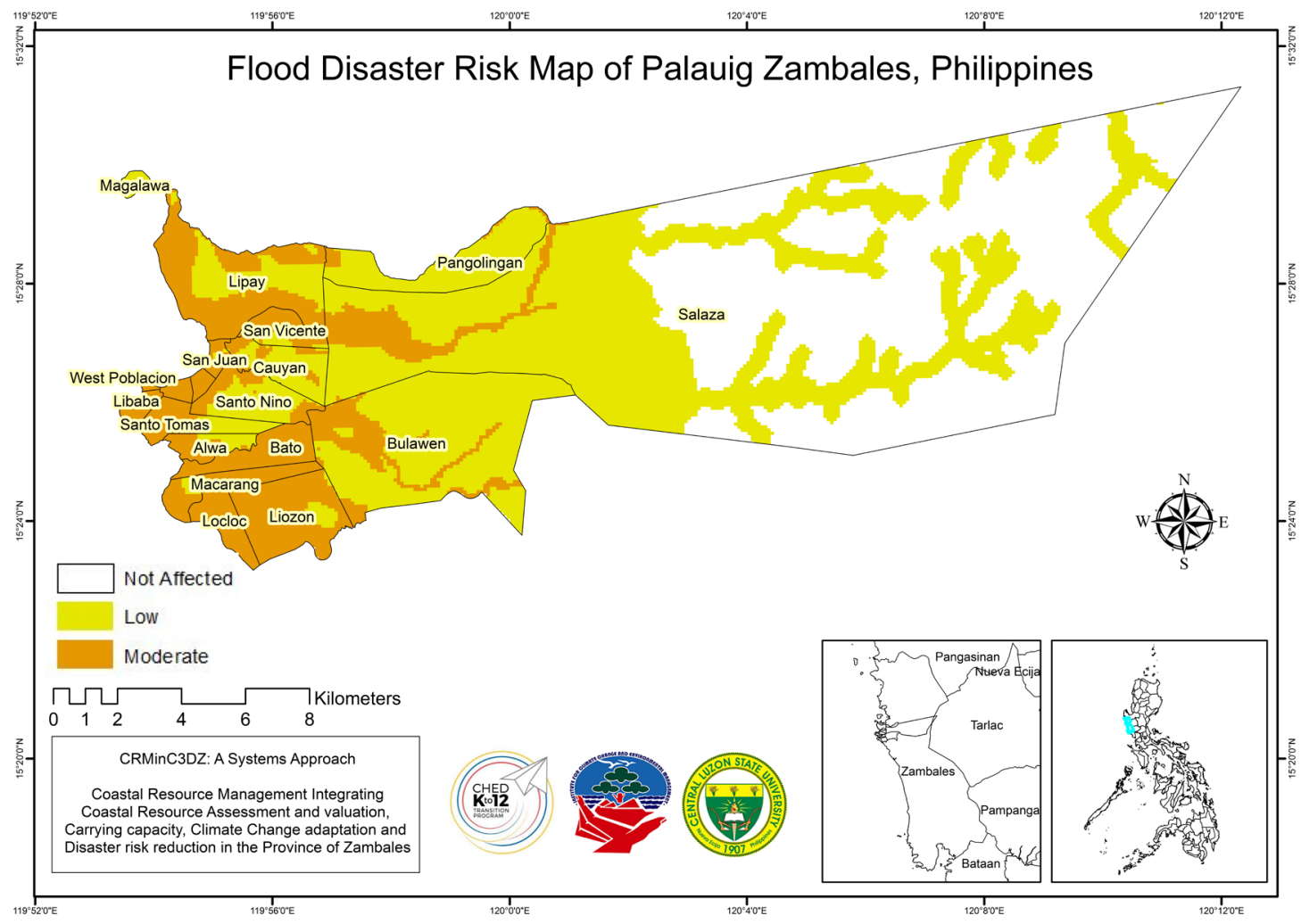

(d)

Figure 10. (a) Flood disaster risk map of Sta Cruz, Zambales; (b) Flood disaster risk map of Candelaria, Zambales; (c) Flood disaster risk map of Masinloc, Zambales; (d) Flood disaster risk map of Paluig, Zambales. 
municipality could result from the insufficient drainage and irrigation canals during unusually heavy rainy days and typhoon periods. However, an estimated area of 16,936 ha. (48.69\%) might experience low flooding. Nonetheless, those that are not affected are found to be those located in the forest part of the barangays as shown in Figure 10(b). Moreover, there are no barangays that could experience high flooding.

Most barangays in Masinloc are highly affected by flood as presented in Figure 10(c). Result of the assessment indicates that an estimated area of 14609 ha. $(42.53 \%)$ are not affected by flood disaster in Masinloc. Only Barangays North Poblacion (100\%) and San Salvador (100\%) have low risk to flooding. Moreover, the rest of the barangays may experience low to moderate risk to flooding. These are low-lying areas affected by the overflow from creek/rivers and excessive surface run-off coming from the adjacent barangays and municipalities. However, flooding in the area usually subside after the period of heavy rains.

Flood disaster risk map of the municipality Palauig is depicted in Figure 10(d). Results of the disaster risk assessment towards flood in Palauig revealed that almost all barangays are moderately affected by flood in terms of disaster risk with an estimated affected land area of 4637 hectares. The barangays that are affected are Barangays Alwa (62.6\%), Bato (99.5\%), Bulawen (20\%), Cauyan (33.7\%), East Poblacion (100\%), Garreta (100\%), Libaba (100\%), Liozon (89.5\%), Lipay (67.9\%), Locloc (100\%), Pangolinan (6.6\%), Salaza (3.1\%), San Juan (90.9\%), San Vicente (77.5\%), Sto. Niño (38.3\%), Sto. Tomas (59.9\%) and West Poblacion (100\%) whereas Barangays Macarang (93.2\%) and Magalawa (100\%) have low risk to flooding. Barangays Liozon, Macarang, Bato, Garreta, Lipay, Cauyan and Sto. Niño is low-lying areas and there are portions located near active rivers and creeks. Moreover, agricultural areas of Barangay Liozon have low to moderate risk to flooding. However, $45.05 \%$ of the municipality are found to be low in flood disaster risk while $35.60 \%$ are not affected by flood. These areas are the mountainous part of the municipality especially Barangay Salazar.

\subsubsection{Landslide}

Mountains can be dangerous places. Many mountain communities live under the threat of earthquakes and rainfall-induced landslides transform into debris flows as they travel down steep slopes. Population growth, climate change and unsustainable natural resource management practices are putting dangerous pressure on the mountain ecosystems and making mountain communities increasingly vulnerable to disasters (FAO, 2015). The Zambales Mountains in the eastern length of the province occupies about $60 \%$ of the total land area of Zambales.

In the municipality of Sta. Cruz there are a few barangays that may be affected by the occurrence of landslide disaster in the area as shown in Figure 11(a). Barangay Babuyan (11.7\%) and the mountainous part of Sta. Cruz are the most affected areas in the municipality in terms of landslide disaster risk. Barangays Bolitoc (1.2\%), Guinabon (0.7\%), Guisguis (1.8\%), Lomboy (3\%), Lucapon North 


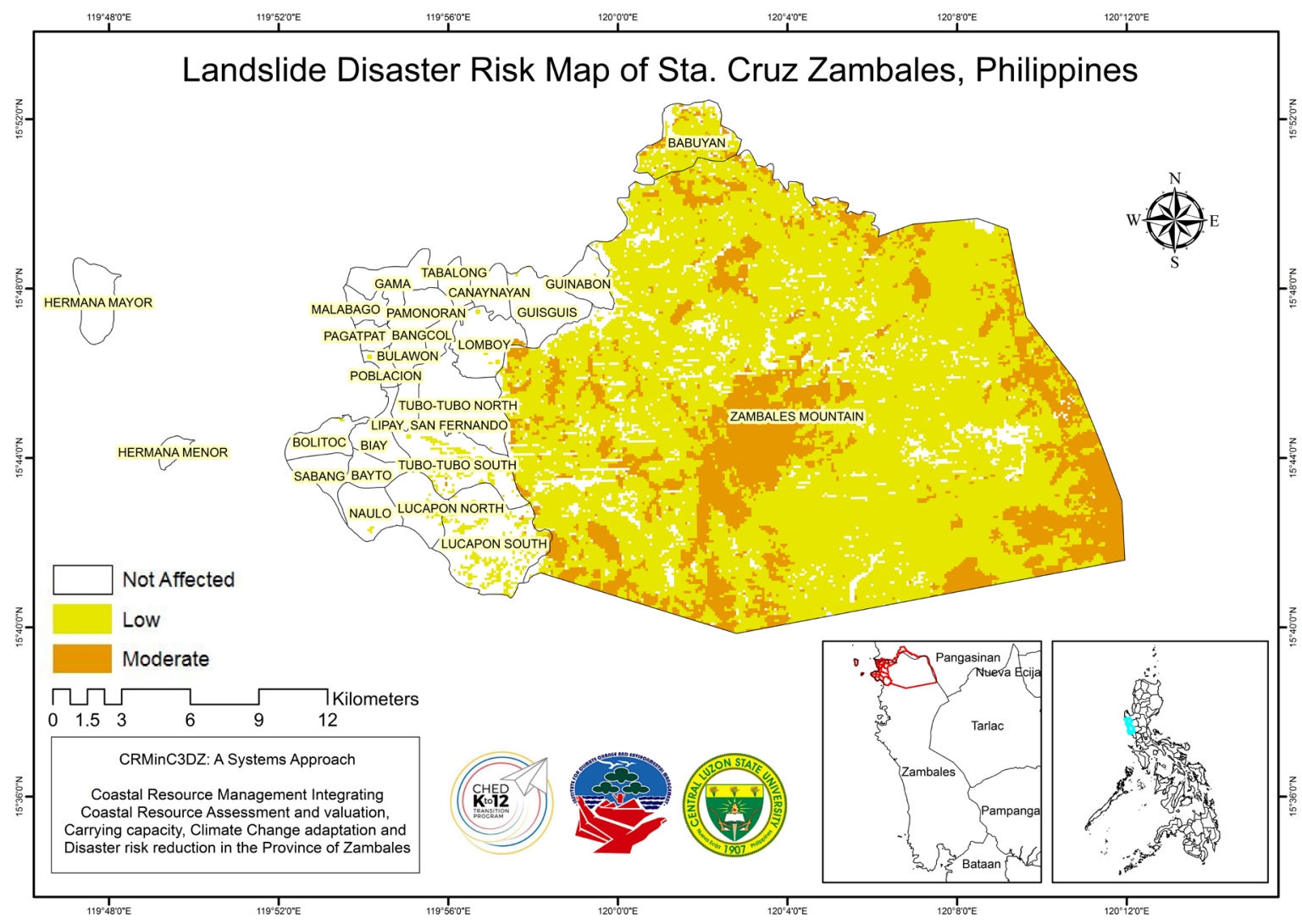

(a)

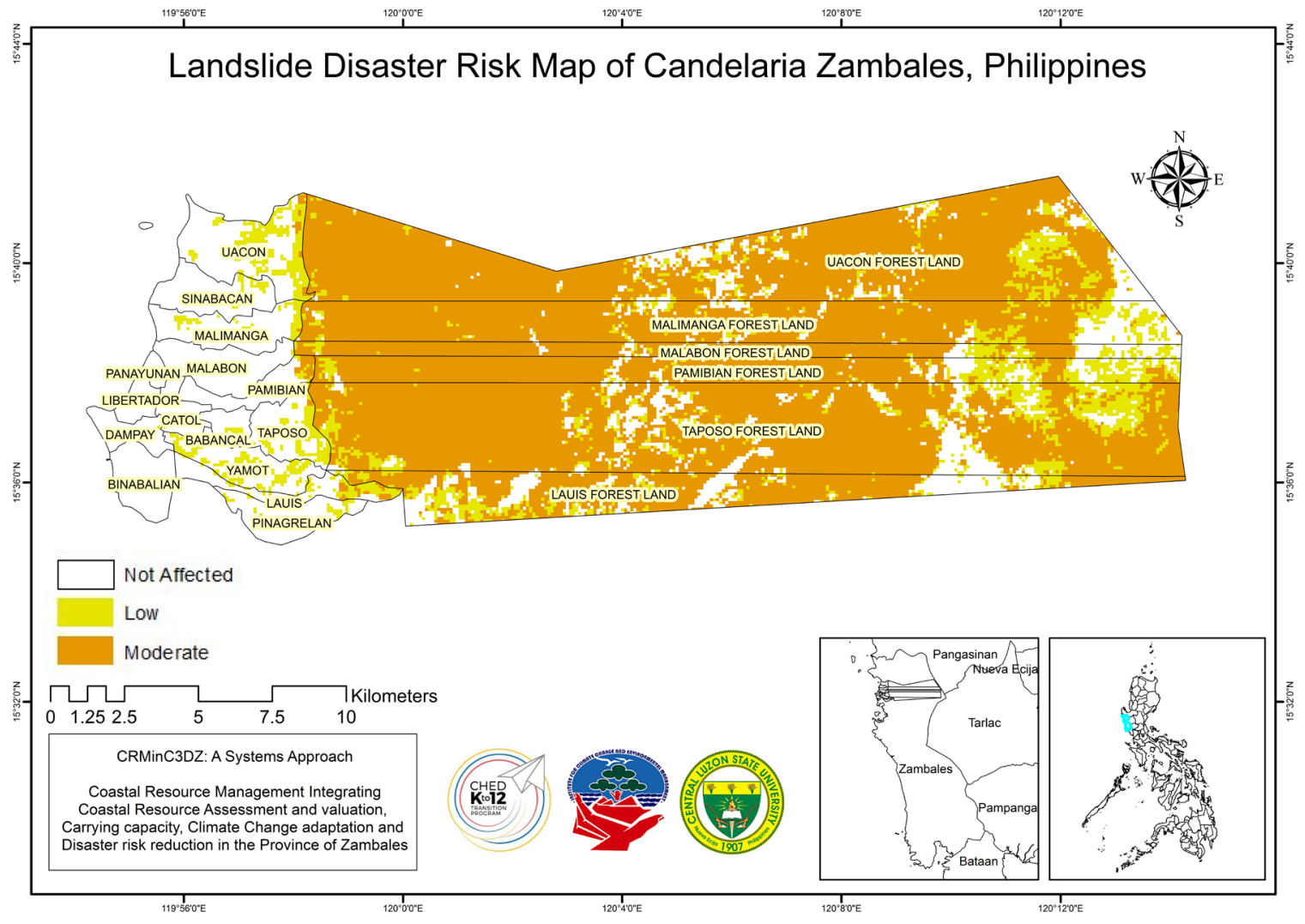

(b) 


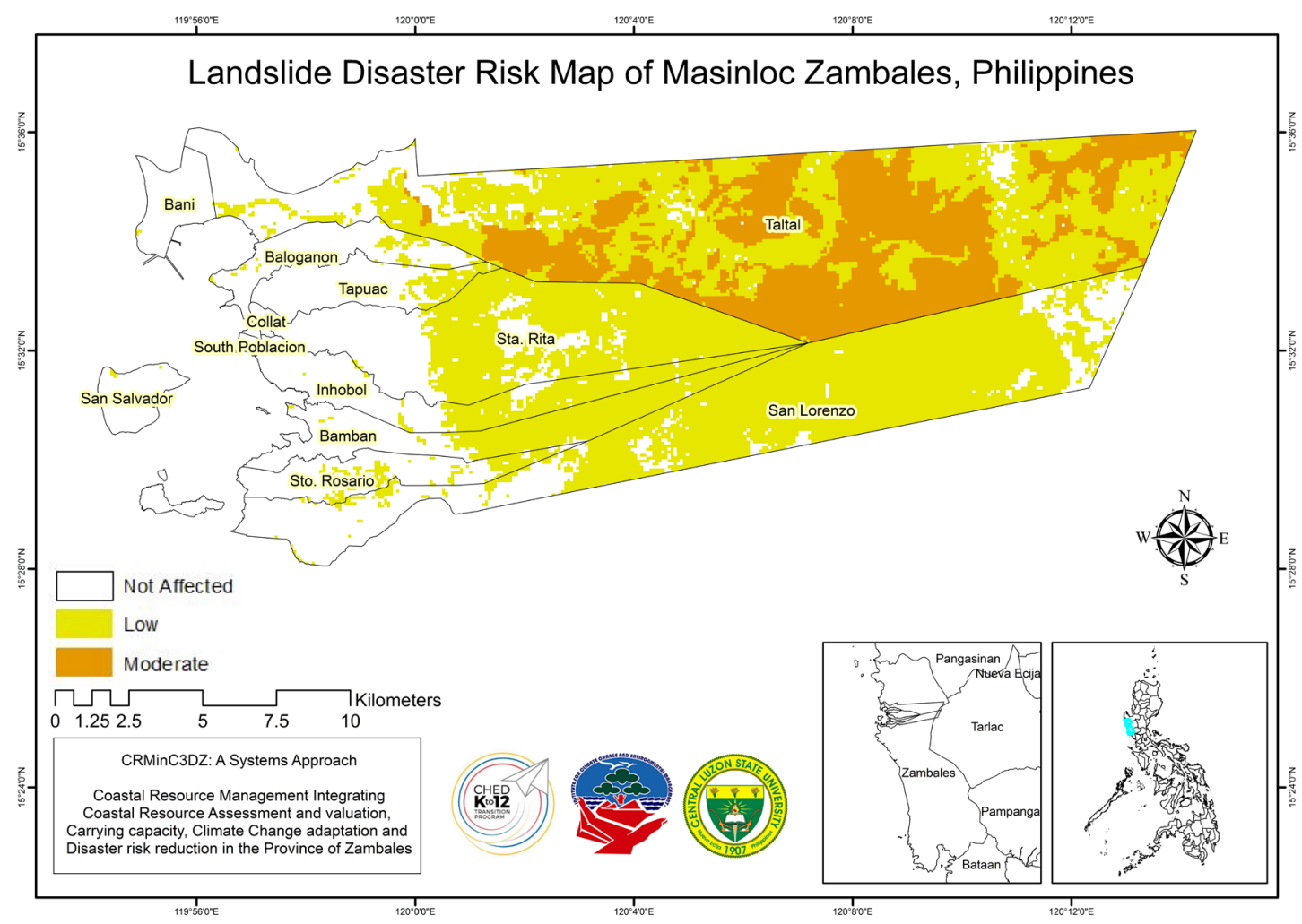

(c)

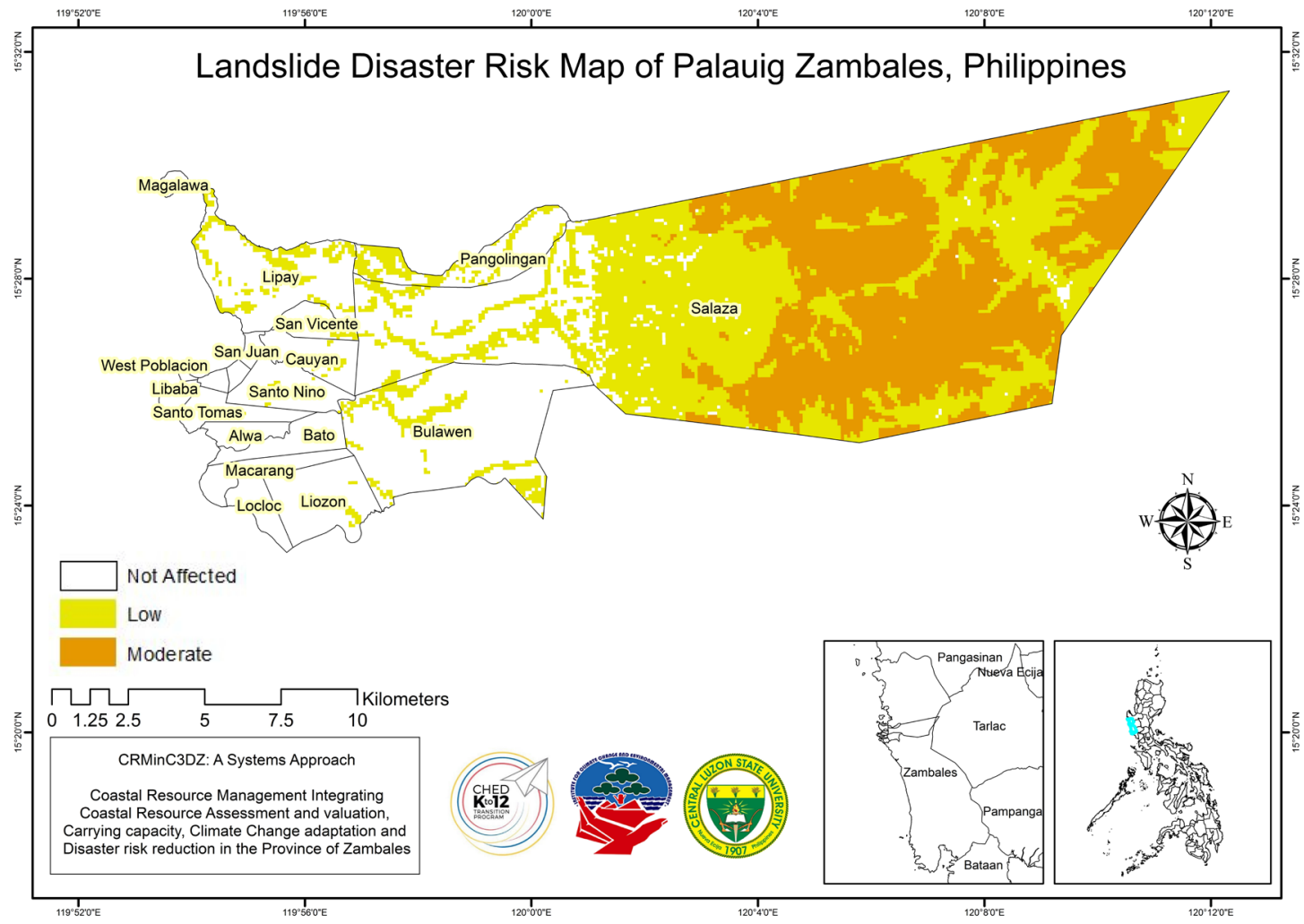

(d)

Figure 11. (a) Landslide disaster risk map of Sta Cruz, Zambales; (b) Landslide disaster risk map of Candelaria, Zambales; (c) Landslide disaster risk map of Masinloc, Zambales; (d) Landslide disaster risk map of Palauig, Zambales. 
(4.5\%), Lucapon South (19.1), Naulo (1\%), Poblacion (2.3\%), Tubo-tubo North $(0.8 \%)$ and Tubo-tubo South (13.4\%) have low to moderate landslide disaster risks. However, the rest of barangays in the municipality are not affected by landslide disaster risks.

Figure 11(b) shows the map of landslide disaster risk of Candelaria. The municipality has almost the same landscape with the municipality of Sta. Cruz. The mountainous part of Barangays Lauis (6.5\%), Malimanga 0.3\%), Pamibian (9.3\%), Pinagrelan $(0.6 \%)$, Taposo $(1.8 \%)$ and Uacon $(3.0 \%)$ are moderately affected by landslide disaster risks.

Figure 11(c) presents the landslide disaster risk map of the municipality of Masinloc, Zambales. It can observed that only Barangay Taltal is moderately affected by landslide disaster risk with an estimated affected land area of $43.9 \%$. Barangays Collat and North Poblacion are $100 \%$ not affected by landslide disaster risks. However, the rest of the barangays have low landslide disaster risks. Although Barangays Bamban, Inhobol, San Lorenzo and Sta. Rita have mountainous parts but they are also affected by low landslide disaster risks because their vulnerability to landslide is low (Figure 11(c)). Moreover, their adaptive capacity to landslide are high. Disaster risk assessment on the various areas is based on the hazard information and derived vulnerability of the municipality (Abdulwahid \& Pradhan, 2017).

The landslide disaster risk map of the municipality of Palauig, Zambales shows that majority of the areas in Barangay Salaza are moderately affected by landslide disaster risks with an estimated affected land area of $43.4 \%$ (Figure 11(d)) Barangay Salaza is situated in the mountainous portion of Palauig whereas Barangays Bulawen (13.8\%), Cauyan (4.6\%), Liozon (2.7\%), Lipay (24.9\%), Locloc (0.4\%), Macarang (0.9\%), Pangolinan (42.1\%), San Vicente (9\%), Santo Niño (5.4\%), and Santo Tomas (0.6\%) obtained low landslide disaster risks. Moreover, the rest of the barangays in Palauig are not affected by landslide disaster risks.

\subsubsection{Storm Surge}

A storm surge is a rise in sea level that occurs during tropical cyclones, over and above the predicted astronomical tides. The storms produce strong winds that push the water into shore, which can lead to flooding. This makes storm surges very dangerous for coastal areas particularly when the storm surge coincides with normal high tide (National Geographic, 2019). Zambales lies on the western shores of Luzon Island along the West Philippine Sea. Its shoreline is rugged and features many coves and inlets.

Storm surge disaster map of Sta. Cruz is presented in Figure 12(a). There are 10 coastal barangays in Sta. Cruz, Zambales. Results revealed that Barangays Lipay (100\%), Malabago (75.1\%) and Poblacion (65.9\%) are highly affected by storm surge in terms of disaster risk while the rest of the barangays are not affected by storm surge. Moreover, two barangays in Sta. Cruz namely Barangays Malabago and Gama might experience storm surge. According to Barangay 


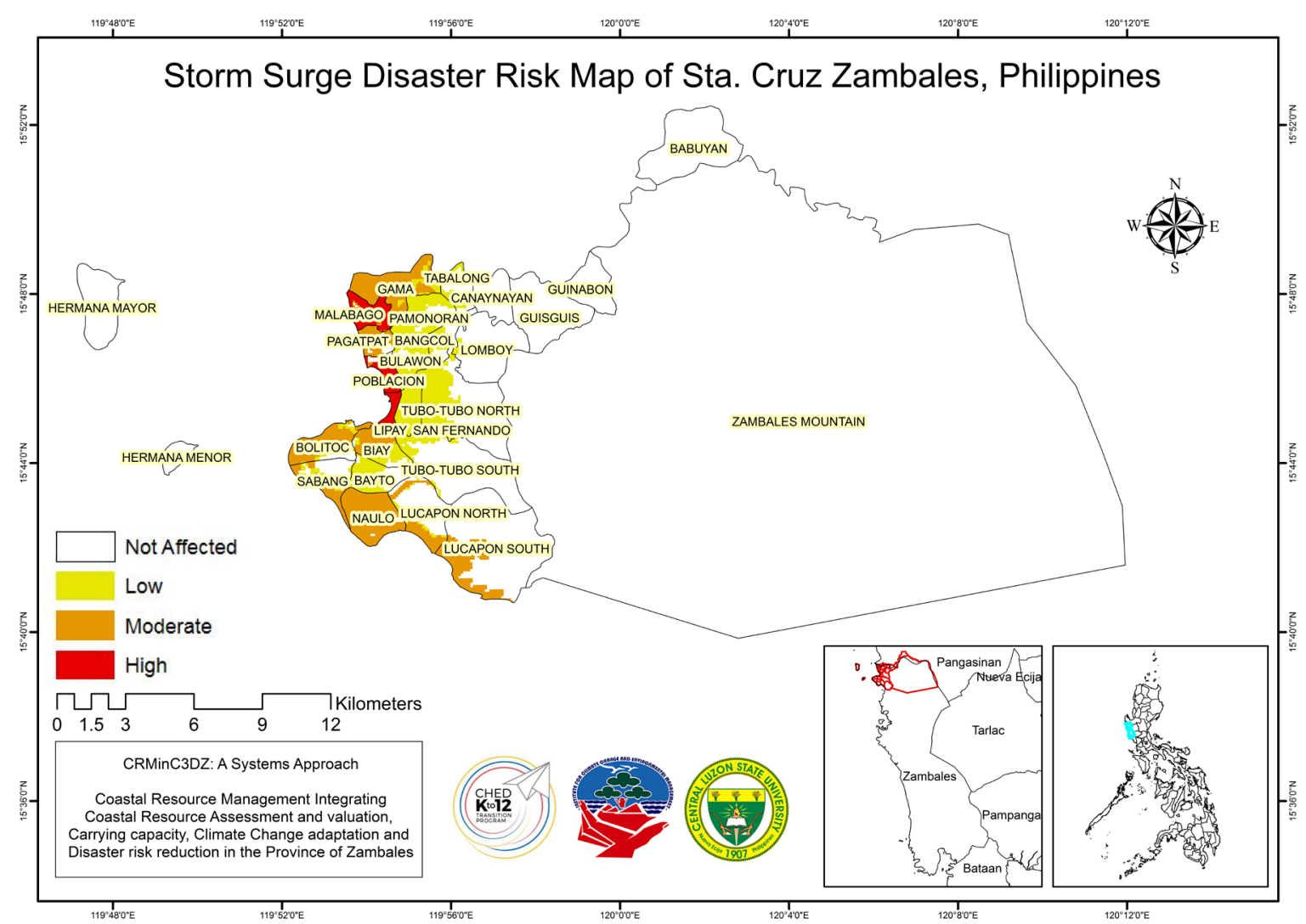

(a)

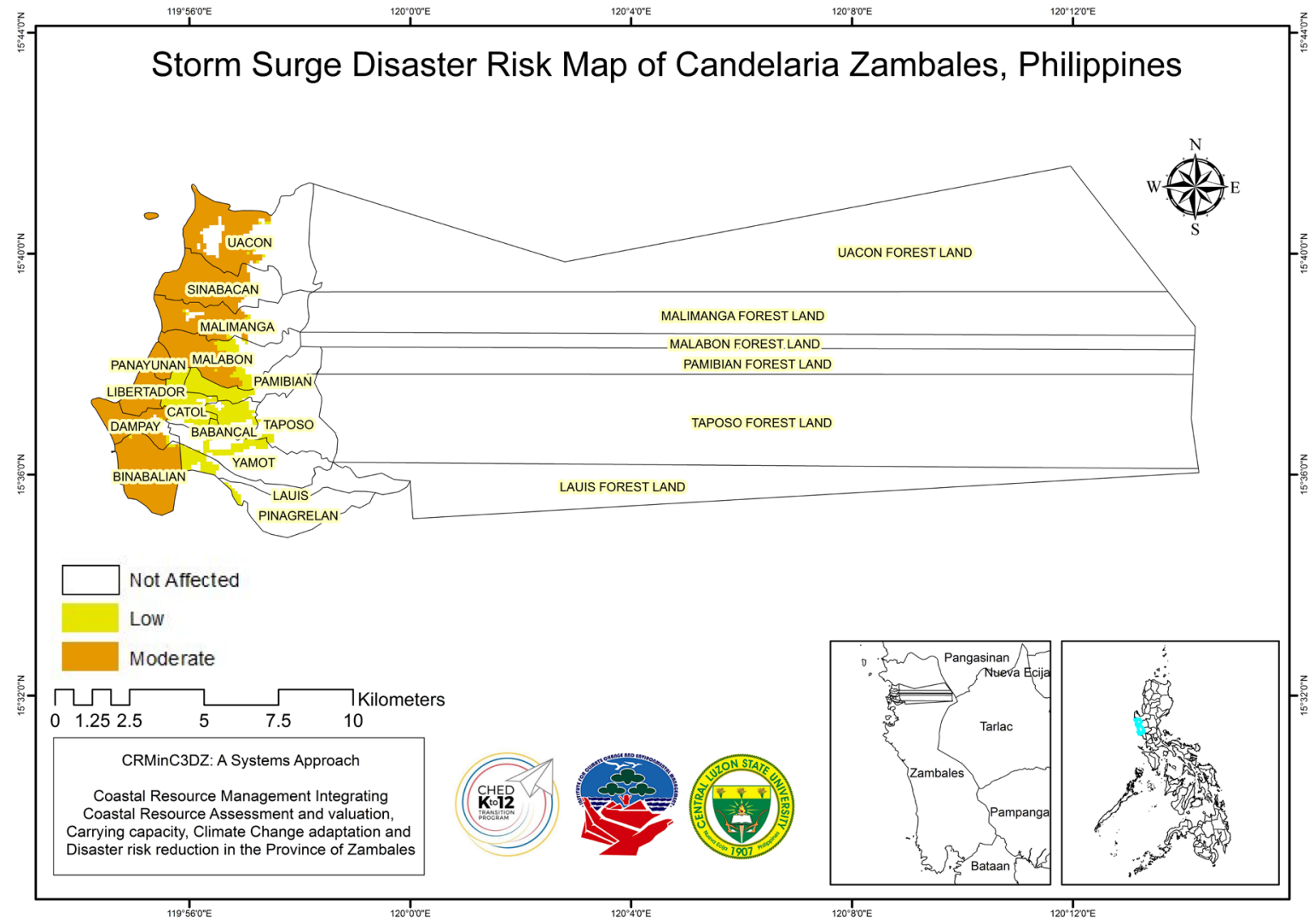

(b) 


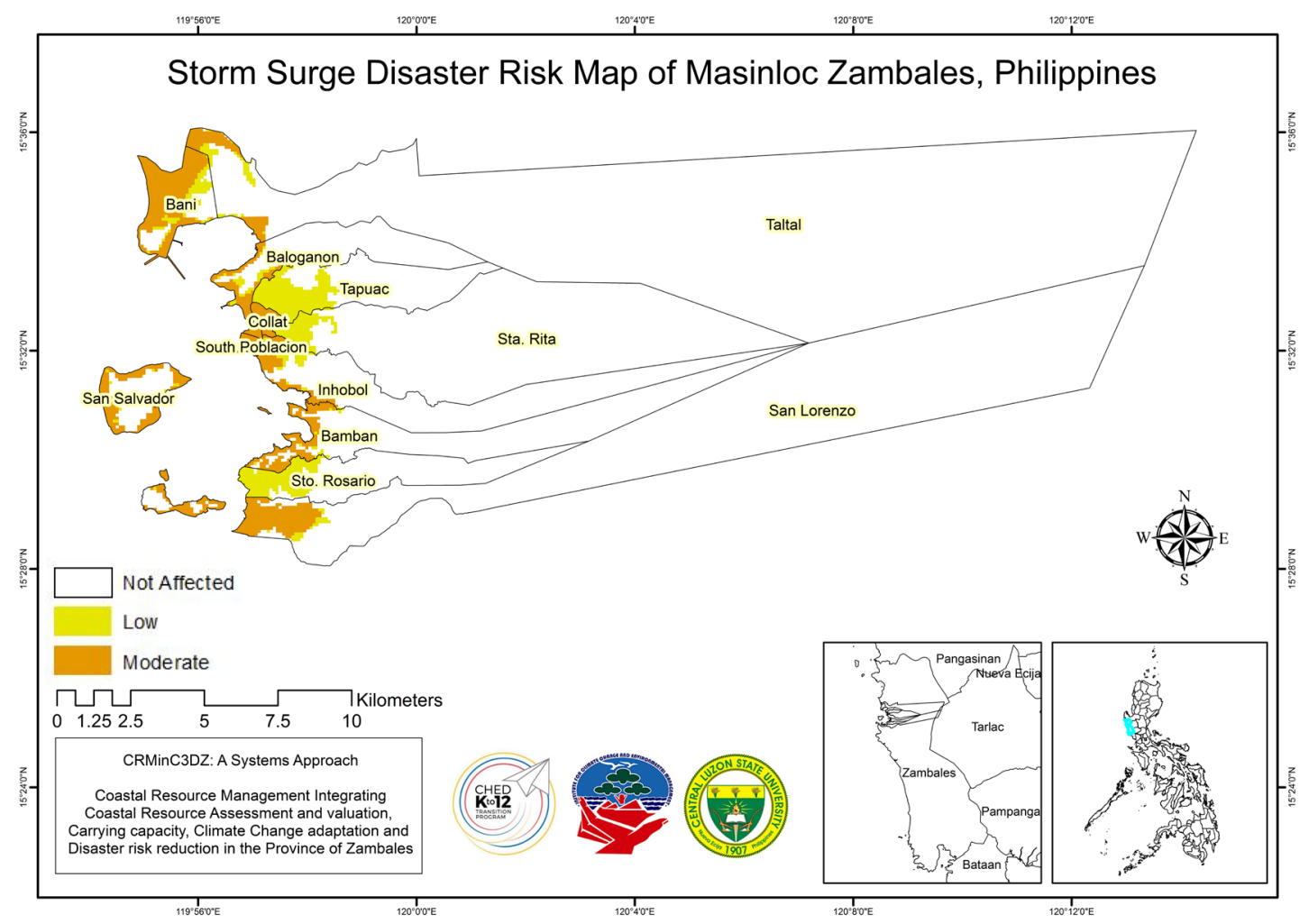

(c)

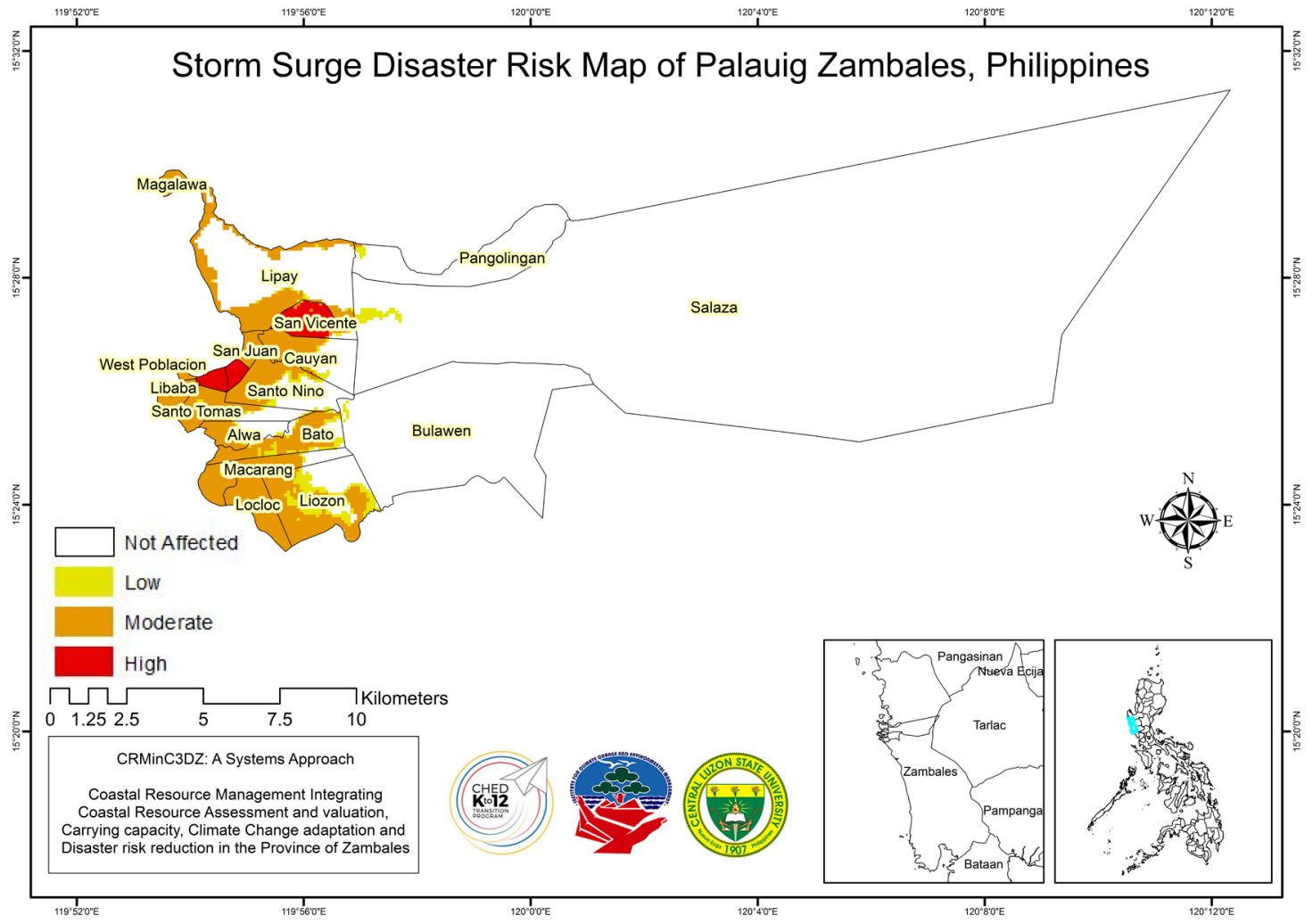

(d)

Figure 12. (a) Storm Surge disaster risk map of Sta Cruz, Zambales; (b) Storm surge disaster risk map of Candelaria, Zambales; (c) Storm surge disaster risk map of Masinloc, Zambales; (d) Storm surge disaster risk map of Palauig, Zambales. 
officials in Barangay Malabago an estimated 20 families will be affected in the area while barangay officials in Gama said that there will be 28 houses which may be affected by the storm surge in the area.

Out of 16 barangays in Candelaria there are 8 barangays which are situated near the coast as shown in Figure 12(b). The results of storm surge disaster risk assessment in Candelaria revealed that all the coastal barangays such as Barangays Binabalian (97.3\%), Dampay (82.6\%), Lauis (1.7\%), Libertador (100\%), Malabon (50.6\%), Malimanga (48.3\%), Panayunan (100\%), Sinabacan (72.9\%) and Uacon (40\%) are moderately affected by storm surge while the rest of the barangays are not affected and have low risks only. Mangrove forest in the coastal areas of the municipality are not sufficient to protect the area to this kind of disaster. In addition, planting of mangrove trees is focused only in the Uacon Lake for conservation and utilization of freshwater lakes.

Almost all barangays in Masinloc are coastal barangays. In terms of disaster risk to storm surge, Masinloc has only three barangays that may experience low disaster risks and these are South Poblacion, Sta. Rita and Tapuac as shown in Figure 12(c). The rest of the barangays in the municipality have moderate risks to storm surge. These three barangays are also found to have low vulnerability to storm surge (Figure 12(c)). However, there are natural barriers present in the municipality like coral reef and mangrove ecosystems. Moreover, seawalls are present in the municipality which have been used to control coastal erosion and protect the municipality from rising sea levels and storm surges.

It can be seen that majority of the barangays in Palauig, Zambales are affected by storm surge except for Barangays Pangolinan, Bulawen and Salaza for these barangays are situated in mountainous part of the municipality (Figure 12(d)). Only three barangays were found to be highly affected by storm surge disaster. These three barangays are East Poblacion (100\%), San Juan (73.4\%) and West Poblacion (94.7\%). These barangays are the most expose and most sensitive to this kind of disaster due to their lack of natural defenses against the storm surge like shallow reef wetlands and barrier islands. In addition, the mangrove ecosystem in these barangays are only few. Moreover, large agricultural lands are present near coastal areas that may be affected by this kind of disaster.

\subsection{Climate Change Impacts as Perceived by the Respondents}

Climate change impacts such as heavy rains, sea level rise, increase in temperature, and strong typhoons are the most prominent impacts that these four coastal municipalities have experienced for the past ten years as perceived by the respondents from the four coastal municipalities (Figure 13).

The Philippines has a high vulnerability to natural hazards which are attributed to the nation's geographic position in Southeast Asia. Natural disasters such as typhoons, earthquakes, floods, volcanic eruptions, landslides, and fires affect the country. Volcanic eruptions and tsunamis are related to the continental plate activity around "the Ring of Fire" (Disaster Management Reference Handbook, 2018). 


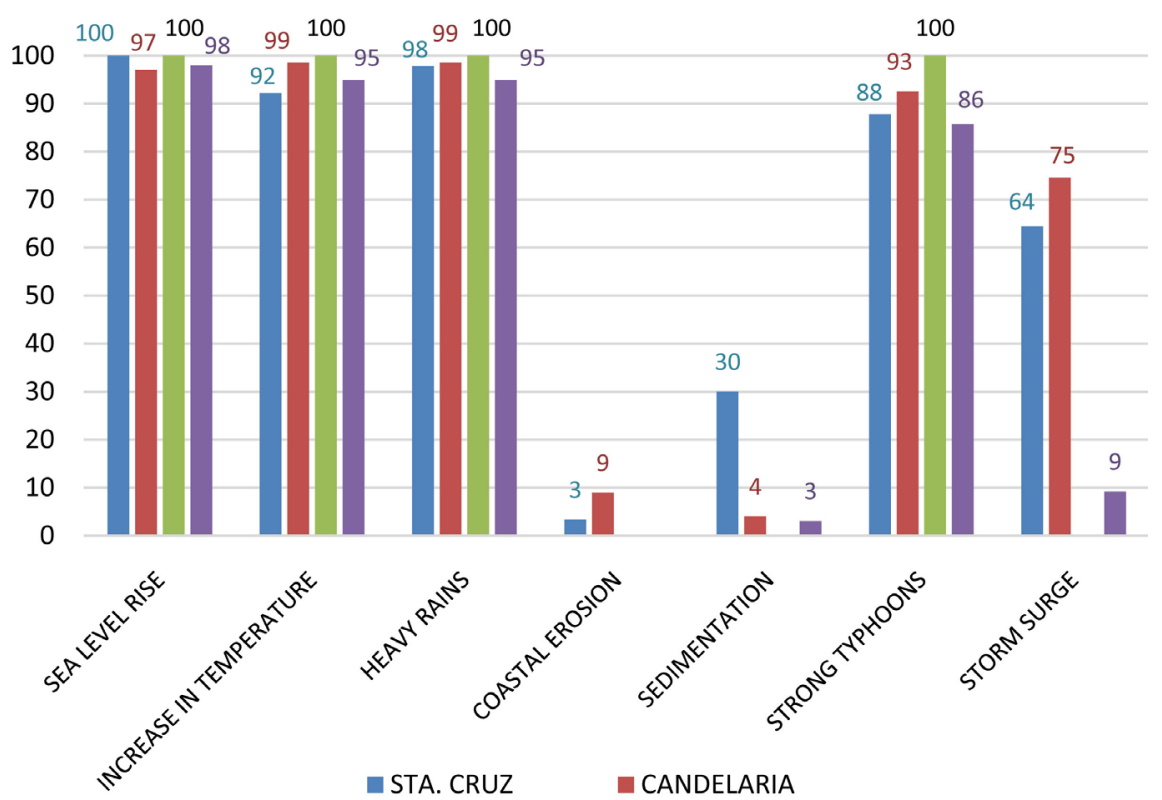

Figure 13. Comparison of climate change impacts on the 4 coastal municipalities of Zambales, Philippines.

By being close to the ocean, people who live and work in coastal areas face unique risks of natural disasters. And as more people move to the coast, natural disasters have the potential to cause ever more damage. Coastal communities are vulnerable to such catastrophic events as hurricanes, tropical storms, and storm surge, and even the flooding and high winds associated with smaller, less intense storms can present major dangers to those living along the coast.

\subsection{Climate Change Science as Perceived by the Respondents}

Figure 14 illustrates the awareness and mindfulness of the coastal communities in the four municipalities of Zambales with regard to climate change and its effects.

Overall, it can be seen that the local communities in the municipalities of $\mathrm{Pa}$ lauig and Masinloc were more aware of the overwhelming effects of climate change while the local communities in Candelaria accounted for the lowest percentage (Figure 14).

\subsection{Community-Based Climate Change Adaptation Strategies}

Table 6 shows the community-based climate change adaptation strategies in the four coastal municipalities in Zambales such as Sta. Cruz, Candelaria, Palauig and Masinloc. Results indicated that the four coastal municipalities have drainage system projects, improvised early warning systems, and established rescue teams per barangay, presence of rescue vehicles, alternative livelihood and presence of emergency/back-up electric supply/generators. However, the coastal municipality of Sta. Cruz and Masinloc are among the municipalities that distributes flood hazard maps to the coastal barangays for their protection and 


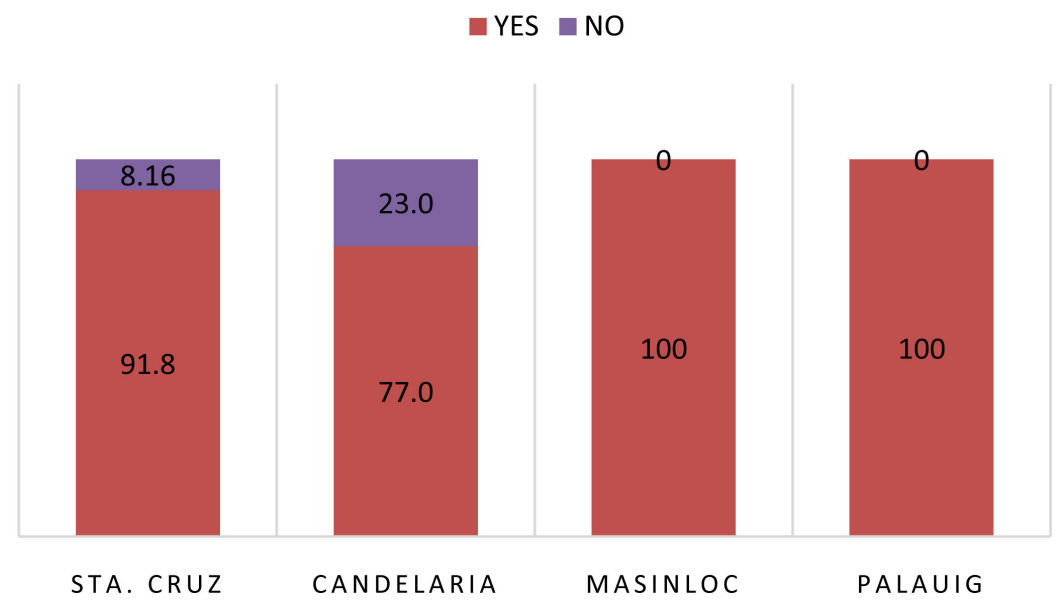

Figure 14. Awareness of climate change in the selected municipalities in Zambales.

Table 6. Community-based climate change adaptation strategies in the four coastal municipalities of Zambales, Philippines.

\begin{tabular}{|c|c|c|c|c|}
\hline \multicolumn{5}{|c|}{ COMMUNITY-BASED APPROACH } \\
\hline ADAPTATION STRATEGIES & STA. CRUZ & CANDELARIA & PALAUIG & MASINLOC \\
\hline Drainage system projects & $\mathrm{x}$ & $\mathrm{x}$ & $\mathrm{x}$ & $\mathrm{x}$ \\
\hline $\begin{array}{l}\text { Infrastructure development } \\
\text { (sea walls, dikes, etc.) }\end{array}$ & $\mathrm{x}$ & $\mathrm{x}$ & & $\mathrm{x}$ \\
\hline Distribution of flood hazard maps & $\mathrm{x}$ & $\mathrm{x}$ & & \\
\hline $\begin{array}{l}\text { Local restriction on the illegal } \\
\text { construction of houses along the } \\
\text { coastal areas/salvage zone }\end{array}$ & $\mathrm{x}$ & $\mathrm{x}$ & & \\
\hline Warning systems (improvised) & $\mathrm{x}$ & $\mathrm{x}$ & $\mathrm{x}$ & $\mathrm{x}$ \\
\hline Established rescue teams (per barangay) & $\mathrm{x}$ & $\mathrm{x}$ & $\mathrm{x}$ & $\mathrm{x}$ \\
\hline $\begin{array}{l}\text { Presence of rescue vehicles } \\
\text { (ambulance, multi-cabs, rubber boats, } \\
\text { dump truck, and motorcycles) }\end{array}$ & $\mathrm{x}$ & $\mathrm{x}$ & $\mathrm{x}$ & $\mathrm{x}$ \\
\hline $\begin{array}{l}\text { Alternative livelihood } \\
\text { (aquaculture, salt making, swine, goat, } \\
\text { and turkey raising, rag-making }\end{array}$ & $\mathrm{x}$ & $\mathrm{x}$ & $\mathrm{x}$ & $\mathrm{x}$ \\
\hline $\begin{array}{l}\text { Presence of emergency/back-up electric } \\
\text { supply/generators (some barangays) }\end{array}$ & & $\mathrm{x}$ & $\mathrm{x}$ & $\mathrm{x}$ \\
\hline Promotion of organic/backyard farming & & & $\mathrm{x}$ & $\mathrm{x}$ \\
\hline Practice of disaster drill & & & $\mathrm{x}$ & $\mathrm{x}$ \\
\hline Widening of floodplains/floodways & & & $\mathrm{x}$ & \\
\hline
\end{tabular}

formulated local policy to prevent the illegal construction of houses along the coastal areas for the protection of the communities during strong typhoons, torrential rains and possible occurrence of storm surge. On the other hand, only Candelaria has a project on widening of floodplains/floodways as a move to protect the local communities on the incidence of floods in their areas. 
Every coastal barangay in the municipality of Sta. Cruz, Candelaria, Masinloc and Palauig have created their adaptation policies for climate change and mitigation measures. Community-based methods through barangay initiatives such as the building of drainage systems and de-clogging programs are one of the priorities of each barangay by removing trash along each barangay's canals to eliminate the cause of flooding before the rainy season. In addition, the Barangay Council considers the widening of floodplains to be one of the priority programs to be done in Candelaria. Through these projects prevention of the effects of climate change such as heavy rains that can cause flooding on low-lying regions could be possible. Construction of sea walls and riprap dikes were also the priority of each coastal barangay. In Barangay Bolitoc, part of Lucapon North in Sta. Cruz as well as in narrow parts of Masinloc e.g. Bani and South Poblacion, the local government and resort owners, constructed sea walls as protection to the local communities to eliminate the impacts of storm surge during typhoon and amihan season.

The Sta. Cruz Project Planning and Development office is tasked to distribute the flood hazard maps; however, majority of the maps are still unfulfilled. Barangays Sabang, Poblacion South, and Lucapon North are the only coastal barangays that obtained these maps from LGU of Sta. Cruz. Limited coastal barangays were aware of Flood Hazard Maps. Considering that only Barangays Bani and Taltal are the only two barangays that have Flood Hazard Maps in Masinloc which are displayed in their barangay halls. While the other barangays based their knowledge on history of floods only to identify the flood prone areas or purok in their area. Meanwhile, Barangay Lipay is the only barangay in $\mathrm{Pa}$ lauig to have a current copy of flood hazard map in their barangay hall that serves as a guide to define flood-prone regions. Flood Warning Signs are also noticeable in many barangays.

Early warning is a significant component of disaster risk reduction. Early action can often stop danger from turning into a human catastrophe by stopping loss of lives and decreasing economic and physical effects. To be efficient and sustainable, they must actively involve the communities at risk. Lack of proven early warning systems in Sta. Cruz has compelled the barangay units to use improvised warning systems. Thru the use of megaphones, it served as the siren to offer alarm signals to the local community during calamity and catastrophe such as typhoon and torrential rains being experienced annually by the inhabitants of Zambales. In the municipality of Candelaria, however, only barangays Libertador and Binabalian used a warning device/system on their society before, during, and after calamities and disasters. These two barangays used megaphone as an improvised device to capture the resident's attention and create an alarm before, during, and after calamities and disasters. However, most barangays in Palauig use megaphones as their device to warn the community to evacuate to the closest evacuation centers. Barangays Lipay and Liozon are the only two barangays that had siren systems that served as early warning systems for use before calamities and catastrophe caused by the impacts of climate change. Meanwhile, Barangay 
Malabon in Candelaria used mobile communications as a way to provide data and early warning signs. However, only Barangay Libaba is the only barangay in Palauig to use text messaging to disseminate early warnings to their community members. Local announcement coming from the Local Government Unit of Masinloc to evacuate serves as the local warning system before, during, and after a disaster/s were practiced. Majority of the coastal barangays used megaphone to modify the local communities to be ready in any instances that a typhoon may happen.

For three reasons, disaster reaction exercises are essential. First, this activity enables individuals to evaluate what will happen when a catastrophe strikes physically. There will be less of a surprise in this manner. Secondly, exercises also allow them to have fresh thoughts and create more efficient plans if they are required. Third, drills check whether emergency equipment are functioning effectively. The Philippine National Red Cross, Philippine National Police and the First Aid Fire Protection Bureau have taught the Barangay Health Workers and Barangay Tanod (Police) in most barangays disaster preparedness drills. In addition, during natural calamities, the Barangay Council and Barangay Police (Tanod) of every barangay in Santa Cruz served as the "Rescue Team." Multi-cabs supplied by the provincial government function as the "Rescue Vehicle" for use by local citizens during calamities or disasters.

Establishing a rescue team is one of the primary priorities of every barangay in Candelaria. Majority of coastal barangays have already set up their rescue teams, led by the Committee on the Environment. One of the main tasks of each rescue team member is to assist each community member in the event of calamities. They also function as the rescuer and take the evacuees to the closest evacuation facilities. Candelaria has constructed a new evacuation center for the use of local communities in the event of a catastrophe in their region. The readiness of rescue cars having "kolong-kolong" (motorcycle with sidecar) is present in Barangays Panayonan, Sinabacan, Uacon, Libertador, and Dampay while Barangays Sinabacan, Malimanga, Malabon, and Dampay have multicabs that serve as rescue vehicles for each barangay's local community. Moreover, Barangay Binabalian has an L300 vehicle that works as an automobile rescue. Early alert systems can be set up to prevent or decrease the effect of risks such as floods, landslides, storms, and forest fires. The importance of an efficient early warning system lies in local individuals recognizing its advantages.

Together with the Philippine National Police (PNP), the Bureau of Fire Protection (BFP), the Department of Social Welfare and Development (DSWD), and the Department of Internal and Local Government (DILG), most of the barangays in Palauig got basic training in disaster preparedness such as first aid, fire drilling and earthquake drilling. In natural disasters, the objective of a search and rescue operation is to rescue the most significant amount of individuals in the shortest moment, while minimizing rescue danger. Concerning this, each barangay in Palauig developed their rescue team to serve as rescue staff before, during, and after calamities. In addition, rescue cars are present in every baran- 
gay. Most of the twelve (12) barangays used multi-cabs (vehicles) while others like Barangay Liozon, Lipay, and Libaba used tricycles while Barangay Santo Tomas and Lipay have "kolong-kolong" and Barangay Magalawa (Island) has a motorboat owing to their proximity to the ocean.

One of the vital needs of every community when there is a catastrophe is a rescue team from the barangay and local government unit. These necessities need to be addressed in every barangay. The establishment of rescue team in every barangay is a must. Every barangay in Masinloc has already created their teams that will respond during calamities and disasters. Barangay Council, Barangay Tanod (Police), Barangay Lupon, and the Barangay Health Workers considered themselves as rescuers. Meanwhile, one of the most common rescue vehicles used by the majority of the coastal barangays in Masinloc were multicabs from the Provincial Government. Moreover, Barangay Bani has an exceptional number of vehicles that are available to use such as an Ambulance, Rubber Boat, Multicab, Dump truck, and Motorcycles (single) for use of each barangay councilor. Also, Barangay Inhobol has an ambulance, an elf truck in Barangay Taltal, "kolong-kolong" (motorcycle with side car) in Barangay South Poblacion, and private tricycles in case of emergency in Barangay Bamban. In Masinloc, there are also members of the barangay who were trained by the Municipal Disaster Risk Reduction Office (MDRRMO), Private Firm (San Miguel Corporation), and Red Cross on Basic First Aid. Members of eight barangays such as Barangays Bamban, Sto. Rosario, San Salvador, Bani, Baloganon, South Poblacion, Taltal, and Inhobol were provided training on first aid in order for them to be ready just in case of emergency.

Power or electricity supply is a necessity in every society. As one of the coastal barangays contingency plans in the four coastal municipalities all of them invest in the procurement of generators. Barangays Libertador and Uacon in Candelaria bought diesel-powered generators in case of emergency and absence of power supply. Generators are now easily accessible for emergency use in some barangays of Sta. Cruz, including Barangays Liozon, Santo Tomas, East Poblacion, Lipay, San Juan, and San Vicente). In Magalawa Island in Palauig, the island's barangay captain only loaned the generator to deal with the impacts of climate change, such as powerful typhoons that may result in a power outage. In the events of power interruptions caused by strong typhoons; generators were used by the following barangays in Masinloc: Barangays San Salvador, Collat, Bamban, South Poblacion, Taltal, Inhobol, Sto. Rosario. While, Bani has two generators ready for emergency use. Purchased generators could provide a minimal supply of electricity to their stakeholders such as charging of smartphones, rechargeable lamps, and for emergencies.

Disaster preparedness relates to measures taken to prepare and decrease the impacts of disasters. That is, to predict and deter accidents, mitigate their effect on vulnerable communities, and react to and efficiently deal with their implications.

Climate change leads to enhanced vulnerability and threat to food shortages, 
food insecurity, and hunger. Droughts, flooding, storms, and heat call for disaster preparedness and efficient emergency response, including early recovery related to long-term growth. Coastal barangays in Palauig allocated 10\% (percent) of their Internal Revenue Allocation (IRA) to the Disaster Fund, which serves as their food security plans and provides food relief before, during, and after disasters.

Majority of the coastal barangays in Masinloc encourage and promote organic and backyard farming to their fellow community members as their source of food in preparation during calamities. To cope up with the low supply and price increase of vegetables in the market due to the effects of climate change. Since the municipality lies in the coastal regions of the Philippines and because of the inconsistent natural supply of fish in the area, aquaculture is one of the alternative livelihoods in Santa Cruz and as an adaptation strategy for climate change. Fish ponds are very imperative in the municipality and have been existent since the 1990s up to the present (2019). Fish products such as milkfish (Bangus) fingerlings, cultivated milkfish (Bangus), shrimp (Vannamei/Suaje) and others such as crabs are being developed, harvested, and promoted to other areas in Pangasinan and Iba, Zambales markets. In Palauig, promoting organic and backyard farming is a requirement for most of the barangays. Barangays like San Vicente, San Juan, Libaba, Sto. Tomas and Liozon empower local communities to grow their fruits and vegetables to decrease the number of pesticides and make them healthier and safer. Growing their fruits and vegetables in their backyard could also save cash and boost physical activity. As the fish population declined in the municipality, local communities encouraged to utilize alternative livelihoods that could serve as the source of revenue in everyday life. Salt production using hearth processing is one of local communities' livelihoods for over thirty (30) years already in Palauig.

\subsection{Ecosystem-Based Climate Change Adaptation Strategies}

Ecosystem-based adaptation (EbA) is an approach that utilizes biodiversity and ecosystem services as part of a holistic strategy for adaptation. EbA often protects communities from the impacts of climate change through win-win results while at the same time offering a range of ecological advantages that are essential to human well-being, such as safe water and food (United Nations Environment Programme). Ecosystem-based approaches to adaptation, or preservation, sustainable management, and ecosystem restoration to assist individuals to adapt to climate change effects are receiving increasing attention as they are available to rural poor in developing nations and can be cost-effective.

Table 7 presents the comparison of ecosystem-based climate change adaptation strategies in the four coastal municipalities of Zambales namely Sta. Cruz, Candelaria, Palauig, and Masinloc. Results revealed that the four coastal municipalities are conducting almost the same ecosystem-based adaptation approaches in order to protect their coastal resources from the effects of climate change except for the utilization and promotion of alternative energy such as 
Table 7. Ecosystem-based climate change adaptation strategies in the four coastal municipalities in Zambales.

\begin{tabular}{|c|c|c|c|c|}
\hline \multicolumn{5}{|c|}{ ECOSYSTEM-BASED APPROACH } \\
\hline ADAPTATION STRATEGIES & STA. CRUZ & CANDELARIA & PALAUIG & MASINLOC \\
\hline Mangrove Planting/Reforestation & $\mathrm{x}$ & $\mathrm{x}$ & $\mathrm{x}$ & $\mathrm{x}$ \\
\hline $\begin{array}{l}\text { Annual/Quarterly Coastal Cleanup } \\
\text { Drive (Local \& International) }\end{array}$ & $\mathrm{x}$ & $\mathrm{x}$ & $\mathrm{x}$ & $\mathrm{x}$ \\
\hline Tree Planting (“Tanim Ng Pag-Ibig”) & $\mathrm{x}$ & $\mathrm{x}$ & $\mathrm{x}$ & $\mathrm{x}$ \\
\hline $\begin{array}{l}\text { Restriction And Limitation To Fishing } \\
\text { Activities (Fine Meshed Net, Triple Net, } \\
\text { And Illegal Fishing) }\end{array}$ & $\mathrm{x}$ & $\mathrm{x}$ & $\mathrm{x}$ & $\mathrm{x}$ \\
\hline $\begin{array}{l}\text { Regular Monitoring Of Marine's } \\
\text { Biodiversity And Ecosystem } \\
\text { Status (Bantay-Dagat) }\end{array}$ & $\mathrm{x}$ & $\mathrm{x}$ & $\mathrm{x}$ & $\mathrm{x}$ \\
\hline Solid Waste Management & $\mathrm{x}$ & $\mathrm{x}$ & $\mathrm{x}$ & $\mathrm{x}$ \\
\hline $\begin{array}{c}\text { Promotion of } \\
\text { Energy-Efficient/Solar-Powered Appliances }\end{array}$ & $\mathrm{x}$ & & $\mathrm{x}$ & $\mathrm{x}$ \\
\hline Clean Air Act of 1999 & $\mathrm{x}$ & $\mathrm{x}$ & $\mathrm{x}$ & $\mathrm{x}$ \\
\hline Marine Protected Area & $\mathrm{x}$ & $\mathrm{x}$ & $\mathrm{x}$ & $\mathrm{x}$ \\
\hline Seagrass Monitoring & $\mathrm{x}$ & & & $\mathrm{x}$ \\
\hline $\begin{array}{l}\text { Restriction to Clear-cutting } \\
\text { (Pruning, Trimming, Etc.) }\end{array}$ & $\mathrm{x}$ & $\mathrm{x}$ & $\mathrm{x}$ & $\mathrm{x}$ \\
\hline
\end{tabular}

solar powered appliances and seagrass monitoring which is not being done in Candelaria.

The ecosystem-based adaptation strategy was one of the techniques used by the four municipalities coastal barangays to fight the effects of climate change. Every year, programs and initiatives such as mangrove planting and reforestation are strictly performed and enforced. The municipal government, schools and universities, rotary clubs, and barangay division participate in this exercise. Each barangay's college pupils, barangay representatives and council, and local communities plant trees every year. The municipal government leads in implementing these activities. There is also a local ordinance that young couples who intend to get married are needed to plant at least two fruit-bearing seedlings in their fields. They called this program "Tanim ng Pag-ibig." The Barangay Council strictly enforces cutting of trees for they must evaluate the age of trees to be cut and inform the Municipal and Provincial head of the Department of Agriculture. Similarly, the pruning and trimming of trees also need assistance from the Clean and Green committee of each barangay.

Planting trees is one of the simplest and most sustainable ways to have a positive impact on the environment of Candelaria. As part of the social responsibility of the community, the barangays of Malimanga, Libertador, and Sinabacan have already planted trees within their respective barangays. To deal with the rising 
market price of vegetables, the barangay community of Sinabacan and Uacon urged their local communities to construct their backyard farms to meet the individual requirements of each household.

Local communities at Palauig barangay levels promote each person to engage in tree planting activity. Most coastal barangays like Brgy. Sto. Tomas and San Juan engaged the Sangguniang Kabataan (SK) in conducting tree planting activities that encourage adolescents to plant trees such as mahogany and pine trees along their respective barangays. Local communities in Barangay Liozon have already planted acacia and butterfly trees last year, while the remainder of the coastal barangays have also undertaken tree planting undertakings. Over the previous few years, the Local Government Unit (LGU) requires young couples who intend to get married to plant a few tree seedlings before they receive a No Marriage Certificate (CENOMAR). Other barangays issue a permit in cutting, pruning, and trimming of trees. They also gather a deposit or fee before going to the activity's procedure.

To minimize the impacts of global warming, one of the activities conducted in some barangays such as Barangays Bani, San Salvador, Collat, North Poblacion, Baloganon, Bamban, South Poblacion, Taltal, Inhobol, and Sto. Rosario is to plant trees as part of the Tree Planting Program in their municipality. This activity is being participated by the Barangay Officials and Councils together with local communities and the personnel of local government unit (LGU). Seedlings are donated by the Department of Environment and Natural Resources (DENR) such as agoho, mango, and mahogany seedlings. As part of the requirement on getting married, the municipalilty of Masinloc requires every couple to plant the seedlings as part of their undying love for each other.

Mangroves safeguard shorelines from damaging winds, waves, and floods from storms and typhoons. Mangrove forests' thick root systems trap sediments from the flowing water down the rivers and off the soil. The mangrove ecosystems also safeguard coral reefs and seagrass meadows from smothering in sediments by filtering out sediments (World Wide Fund, 2017). The mangrove trees assist in stabilizing the shoreline and preventing wave and storm erosion. Coastal harm from hurricanes and typhoons is more severe in regions where mangroves are diminishing. Barangays Malabon, Malimanga, Libertador, Sinabacan, and Binabalian in Candelaria are the coastal barangays that forced their local communities to plant mangrove trees to avoid erosion by stabilizing sediments with their tangled root systems. They also thought that mangroves could preserve water quality and clarity, filter pollutants, and trap sediments from the soil. Coastal barangays in Palauig and Masinloc encouraged every citizen to participate in planting mangrove trees that are thought by local inhabitants to help lessen the effects of storm surges and enormous waves from typhoons and storms. The Bantay Dagat in their respective areas are the ones monitoring the mangrove ecosystems. Additionally, the presence of rich population of seagrass in many coastal barangays of Masinloc is an indication that Masinloc practiced very good conservation strategies due to the awareness of local communities on 
how seagrass act as the breeding ground for many varieties of fish. In addition, Barangay Malabon is the only barangay in Candelaria that is involved in preserving the area's seagrass ecosystem by tapping the Bantay-Dagat also to safeguard and monitor the municipality's seagrass ecosystem.

Furthermore, the local communities celebrate and implement International Coastal Clean-Up in every coastal barangay of the four municipalities in Zambales every September of the year to assist the coastal environment in replenishing and maintaining its natural characteristics. Some barangays also perform their own Barangay Coastal Clean Up at least one or two times a year reducing Santa Cruz's coastal pollution issues. This activity is the most significant volunteer effort for the health of the ocean. It is held annually every third Saturday of September, individuals around the globe gather on beaches, coasts, rivers, waterways, and underwater dive sites to remove trash and record data on the accumulated debris. Results of this activity will help in the attainment of better waste management policies/plans, product packaging designs, and people's environmental awareness.

The Bureau of Fisheries and Aquatic Resources (BFAR) has strictly enforced restrictions and limitations on fishing operations in the coastal waters of Zambales. The use of fine-meshed nets is not allowed for the fishermen in the area. Illegal activities such as the use of dynamite (bong-bong), sodium cyanide, and compressor are also forbidden and strictly controlled by the "Bantay Dagat" (guardians of the sea). Fishermen who continue to exercise these illegal operations will be fined and may face imprisonment from six (6) months to two (2) years.

The barangays in Sta. Cruz strictly implement smoke-belching and garbage burning under the 1999 Clean Air Act. Unfortunately, reports from some residents in every Santa Cruz barangay found that some residents continue to burn trash owing to inconsistent garbage collection. Candelaria's coastal barangays strictly implement Republic Act No. 8749, otherwise known as the Philippine Clean Air Act, an extensive air quality management policy and program aimed at achieving and maintaining good air for all Filipinos. Garbage burning was also forbidden in all barangays to eliminate greenhouse gas emissions that contribute to global warming. Moreover, Barangays Libertador and Uacon began using energy-efficient equipment to lessen the contribution of carbon dioxide to the atmosphere. The municipality of Palauig strictly implements also the 1999 Philippines Clean Air Act (Republic Act No. 8749), which describes the steps taken by the government to decrease air pollution and integrate environmental protection into its development plans. In addition, local communities at Palauig barangay levels promote each person to engage in tree planting operations. Moreover, the strict implementation of Clean Air Act of 1999 was practiced by all of the coastal barangays in Masinloc. Prohibition of burning of garbage in every barangay was strictly executed to eliminate the contribution of greenhouse gases in the ozone layer. 
Nevertheless, residents in Sta. Cruz are still applying the Solid Waste Management Act, and they are segregating their waste. Also, each family in all coastal barangays in Candelaria practices and performs the solid waste management. Waste segregation is adept as part of waste management by dividing biodegradable and non-biodegradable wastes. To tackle the country's increasing issue of solid waste. The Materials Recycling Facility (MRF) was launched specifically in the coastal barangays of Palauig to implement Republic Act 9003 (Ecological Solid Waste Management Act of 2000). The biodegradables are for marketing purposes, and the non-biodegradable materials are shipped to a landfill or other disposal facility. Material Recovery Facility (MRF) is also present in majority of coastal barangays in Masinloc. Waste management is also being rigorously practiced to segregate the non-biodegradable and biodegradable wastes easily.

In reducing the greenhouse gases in the environment, the coastal barangays are urged by the local community to use energy-efficient devices (refrigerators with energy guide stickers), LED lamps, and solar-powered streetlights. However, owing to an absence of budget and fund, other barangays were unable to implement this strategy; nevertheless, they still encourage these operations to reduce the effects and impacts of climate change. The use of energy-efficient and solar-powered appliances was also one of the priorities in every coastal barangays in Masinloc. Barangay Bani is one of the model barangay that promote the use of the solar-powered and energy-efficient appliances. Street lights built in the streets of the barangay are all solar-powered. In Barangay Baloganon there are a few streetlights that are being powered by solar energy while South Poblacion practiced the use of led lights in their barangay.

The Masinloc and Oyon Bays Marine Reserve (MOBMR) is one of the first National Integrated Protected Area System (NIPAS) sites declared by President Fidel Ramos through PP 231 on August 19, 1993. It has a total of 7568 hectares of coastal areas and islands within the bays in Masinloc, Zambales (Dizon, et al., 2013). One of the main activities of the municipality of Masinloc is to preserve the Marine Protected Areas (MPA) such as fish sanctuaries and mangrove ecosystems. The Municipal Environmental and Natural Resources Office (MENRO) tapped every coastal barangay to monitor and report the current status of each MPA.

\section{Conclusion and Recommendations}

Application of remote sensing technology showed that coastlines have changed in the four municipalities in Zambales after a span of ten years. Sea level rise occurred in Sta. Cruz and Masinloc whereas sedimentation took place in the coastlines of Candelaria and Palauig. Three major disasters that have devastating climate change impacts were assessed in this study namely flood, landslide, and storm surge using remote sensing and GIS technologies. Twelve hazard maps, 12 vulnerability maps and 12 disaster risk maps were produced. Based on the flood vulnerability and disaster risk assessments, the municipality of Palauig was the most prone or vulnerable to flooding and storm surge compared to other muni- 
cipalities while the municipality of Candelaria was the most susceptible to landslide compared to Sta. Cruz, Masinloc and Palauig. In response to tackle the detrimental effects of climate change, the four municipalities have conducted community-based climate change adaptation strategies and implemented some measures in order to improve the resiliency of their local communities such as provision of early warning systems, formation of rescue teams, presence of rescue vehicles and equipment, practice of disaster drill, development of drainage system projects and establishment of alternative livelihood. Morever, the four coastal municipalities are conducting almost the same ecosystem-based adaptation approaches in order to protect their coastal resources from the effects of climate change which include mangrove reforestation, coastal clean-up, tree planting, monitoring of Marine Protection Areas (MPAs) and marine biodiversity, solid waste management, and strict implementation of Clean Air Act.

Disaster preparedness is fundamental and vital to every municipality in order for the local communities to be safe and resilient from the effects of climate change. To reduce disaster impacts, more efforts should be applied by the local government units towards development and maintenance of their own disaster risk reduction management measures and plans. Moreover, the municipalities must exert efforts to improve their disaster preparedness plan to specifically identify the areas that are prone to different hazards and to have vulnerability and disaster risk maps for disaster vigilance and alertness for the safety and welfare of the local communities. Further study must also be done to conduct studies on geophysical changes through remote sensing and GIS in coastal resources.

\section{Acknowledgements}

We would like to convey our heartfelt gratefulness to our funding agency, Commission on Higher Education (CHED)-DARE-TO K12 Program for the trust and confidence especially in our abilities to come up with significant outputs and in the attainment of our objectives. The Project Research Team would also like to thank the local government units of Palauig, Masinloc, Candelaria and Sta. Cruz, Zambales for their invaluable support, cooperation and provision of secondary data as well as to the members of the barangay council of the different barangays included in the study areas for their assistance during the conduct of the study.

\section{Conflicts of Interest}

The authors declare no conflicts of interest regarding the publication of this paper.

\section{References}

Abdulwahid, W. M., \& Pradhan, B. (2017). Landslide Vulnerability and Risk Assessment for Multi-Hazard Scenarios Using Airborne Laser Scanning Data (LIDAR). Landslides, 14, 1057-1076. https://doi.org/10.1007/s10346-016-0744-0 
Department of Environmental and Natural Resources (DENR) (2013). National Water Quality Status Report.

https://emb.gov.ph/wp-content/uploads/2019/08/NWQSR-2006-2013.pdf

Disaster Management Reference Handbook (2018). Philippines: Disaster Management Reference Handbook.

https://reliefweb.int/report/philippines/philippines-disaster-management-reference-ha ndbook-march-2018

Dizon, E. C., Geronimo, R. C., \& Quicho, R. (2013). Benchmarking the Management Effectiveness of Nationally-Managed Marine Protected Areas in the Philippines with Policy Recommendations: Final Report.

http://www.coraltriangleinitiative.org/sites/default/files/resources/58 Benchmarking\% 20the $\% 20$ Management $\% 20$ Effectiveness $\% 20$ of $\% 20$ Nationally-Managed $\% 20$ Marine $\% 20$ Protected\%20Areas\%20in \%20the\%20Philippines\%20with\%20Policy\%20Recommendation s Final\%20Report.pdf

Du, Y., Ding, Y., Li, Z. X., \& Cao, G. W. (2015). The Role of Hazard Vulnerability Assessments in Disaster Preparedness and Prevention in China. Military Medical Research, 2, 27. https://doi.org/10.1186/s40779-015-0059-9

Espaldon, M. V., Centeno, H. G., \& Tiburan Jr., C. (2016). Vulnerability Indicators. Handout.

FAO (Food and Agriculture Organization) (2015). Disaster Risk Management.

Gordon, A. (2000). Ocean Stratification and Circulation. http://xtide.ldeo.columbia.edu/mpa/Clim-Wat/Climate/lectures/ocean

Greentumble (2016). What Are the Human Causes of Floods. https://greentumble.com/what-are-the-human-causes-of-floods/\#: :text=Due\%20to\%2 0an\%20increased\%20level,experiencing\%20increased\%20precipitation $\% 20$ and $\% 20$ floo ding

IDRC (International Development Research Centre) (2015). Parts of Philippines May Submerge Due to Global Warming. ScienceDaily. https://www.sciencedaily.com/releases/2015/10/151021104913.htm

IPCC (Intergovernmental Panel on Climate Change) (2001). Climate Change 2001: Synthesis Report. https://www.ipcc.ch/site/assets/uploads/2018/05/SYR TAR full report.pdf

IPCC (Intergovernmental Panel on Climate Change) (2007). Climate Change 2007: Synthesis Report. https://www.ipcc.ch/site/assets/uploads/2018/02/ar4 syr full report.pdf https://doi.org/10.1017/CBO9780511546013

National Geographic (2019). Storm Surge. https://www.nationalgeographic.org/encyclopedia/storm-surge

Paz-Alberto, A. M., De Dios, M. J. J., Alberto, R. P., \& De Guzman, C. H. E. A. (2018). Climate Change Impacts and Vulnerability Assessment of Selected Municipalities and Agroecosystems to Support Development of Resilient Communities and Livelihoods in Nueva Ecija, Philippines. American Journal of Climate Change, 7, 295-335.

http://www.scirp.org/journal/ajcc https://doi.org/10.4236/ajcc.2018.72019

Paz-Alberto, A. M., Pakaigue, M. A., Bulaong, E. P., Sison, M. J. M., \& Lao, R. B. (2016). River Morphology and Rivel Channel Changes in Dagupan River, Pangasinan, Philippines. International Journal of Applied Remote Sensing and GIS, 3, 35-44.

Philippine Mangroves: Biodiversity, Conservation and Management (2014). 
https://mangroveecology.com/mangrove-summit/northwestern-luzon/zambales

Taguiam, C. G., \& Quiambao-Marquez, C. B. (2016). Coastal Households' Perception of Sea Level Rise in Quezon Province, Philippines. FAO AGRIS: International Information System for the Agricultural Science and Technology. https://agris.fao.org/agris-search/search.do?recordID=PH2017000507

UNISDR (United Nations International Strategy for Disaster Reduction) (2004). Living with Risk: A Global Review of Disaster Reduction Initiatives.

https://www.preventionweb.net/publications/view/657

UNISDR (United Nations International Strategy for Disaster Reduction) (2005). Words into Action Guidelines: National Disaster Risk Assessment. In Support the Sendai Framework for Disaster Risk Reduction 2000-2015.

UNISDR (United Nations International Strategy for Disaster Reduction) (2017). Words into Action Guidelines: National Disaster Risk Assessment. In Support the Sendai Framework for Disaster Risk Reduction 2015-2030.

USEPA (United States Environmental Protection Agency) (2002). National Recommended Water Quality.

World Wide Fund (2017). Mangrove Importance.

https://wwf.panda.org/our work/oceans/coasts/mangroves/mangrove importance 